Report of Investigation 2020-10

\title{
SHORELINE CHANGE AT ALASKA COASTAL COMMUNITIES
}

Jacquelyn R. Overbeck, Richard M. Buzard, Mark M. Turner, Katie Y. Miller, and Roberta J.T. Glenn
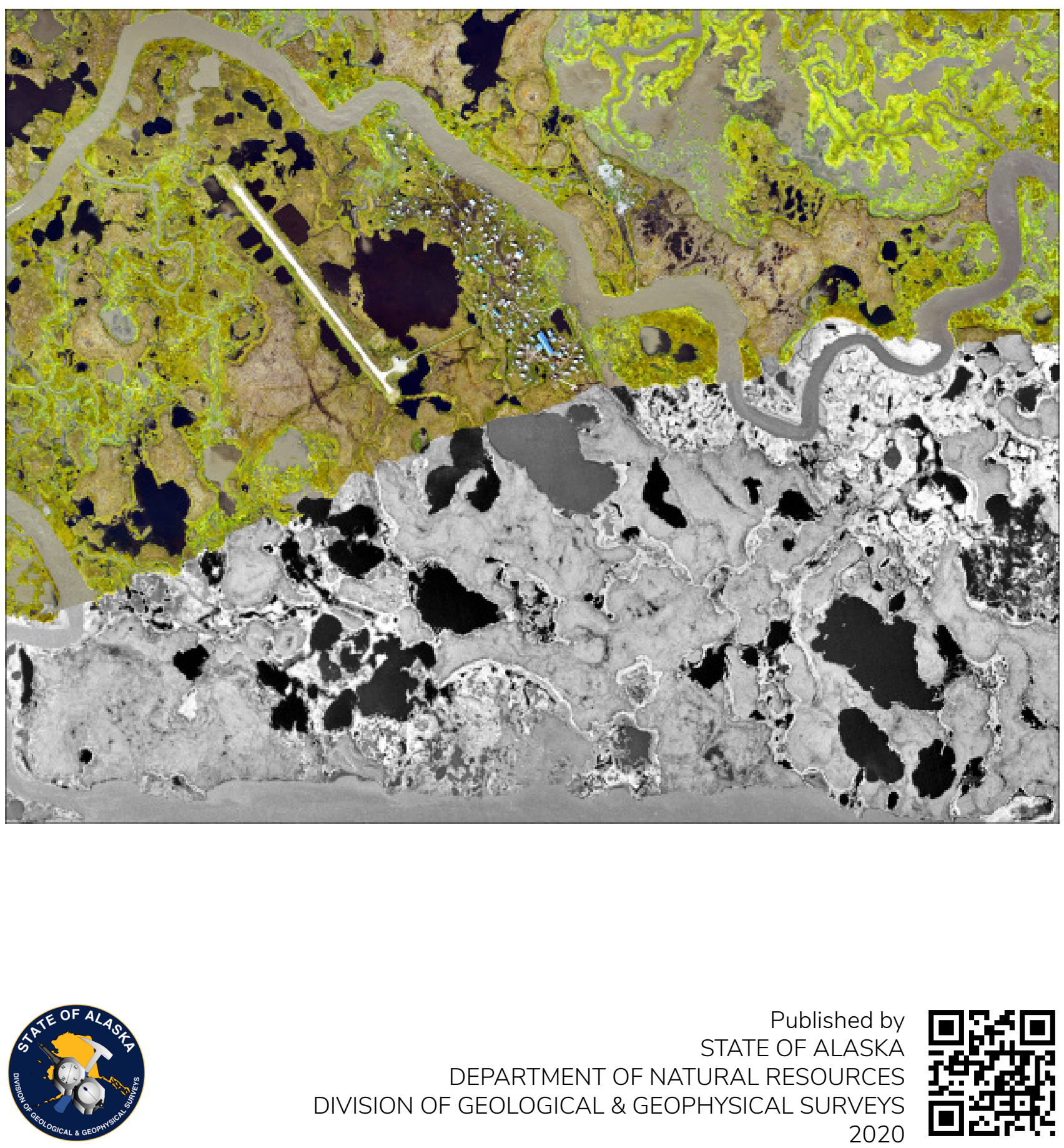
Cover. Shoreline change at Newtok, Alaska. Black and white image from 1951 and color image from 2015. 


\section{SHORELINE CHANGE AT ALASKA COASTAL COMMUNITIES}

Jacquelyn R. Overbeck, Richard M. Buzard, Mark M. Turner, Katie Y. Miller, and Roberta J.T. Glenn

Report of Investigation 2020-10

State of Alaska

Department of Natural Resources

Division of Geological \& Geophysical Surveys 


\section{STATE OF ALASKA}

Mike Dunleavy, Governor

\section{DEPARTMENT OF NATURAL RESOURCES}

Corri A. Feige, Commissioner

\section{DIVISION OF GEOLOGICAL \& GEOPHYSICAL SURVEYS}

Steve Masterman, State Geologist and Director

Publications produced by the Division of Geological \&

Geophysical Surveys (DGGS) are available for free download

from the DGGS website (dggs.alaska.gov). Publications on

hard-copy or digital media can be examined or purchased in

the Fairbanks office:

Alaska Division of Geological \& Geophysical Surveys

3354 College Rd., Fairbanks, Alaska 99709-3707

Phone: (907) 451-5010 Fax (907) 451-5050

dggspubs@alaska.gov|dggs.alaska.gov

\section{DGGS publications are also available at:}

Alaska State Library,

Historical Collections \& Talking Book Center

395 Whittier Street

Juneau, Alaska 99811

Alaska Resource Library and Information Services (ARLIS)

3150 C Street, Suite 100

Anchorage, Alaska 99503

\section{Suggested citation:}

Overbeck, J.R., Buzard, R.M., Turner, M.M., Miller, K.Y., and Glenn, R.J., 2020,

Shoreline change at Alaska coastal communities: Alaska Division of Geological \& Geophysical Surveys Report of Investigation 2020-10, 35 p., 43 sheets.

http://doi.org/10.14509/30552
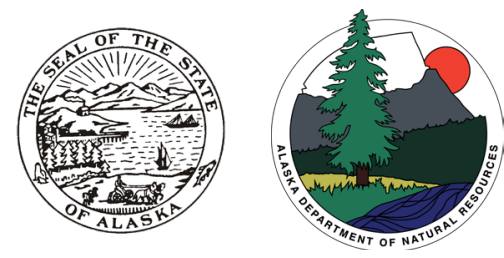


\section{Contents}

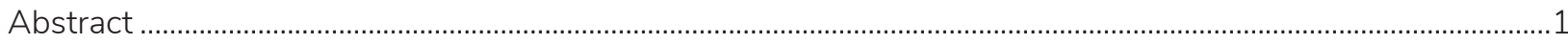

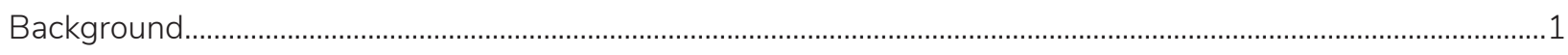

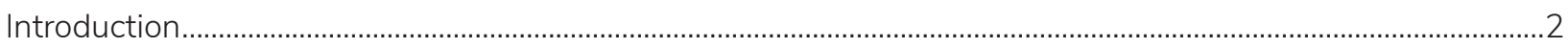

Data

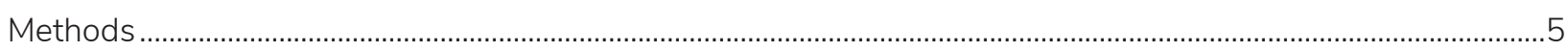

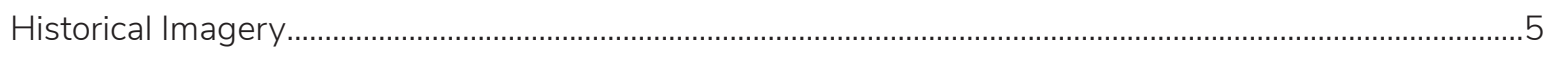

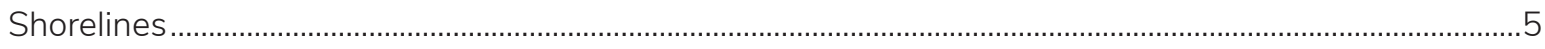

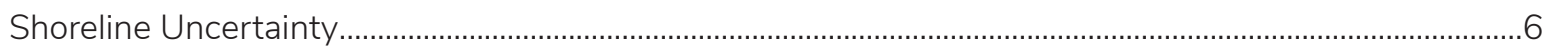

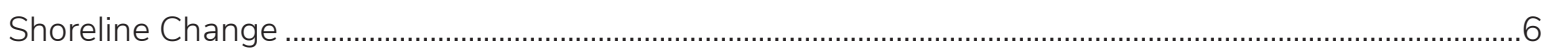

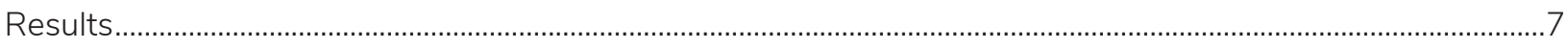

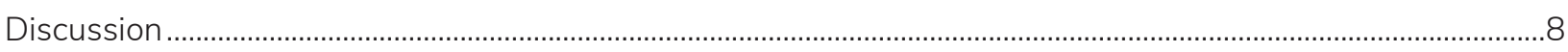

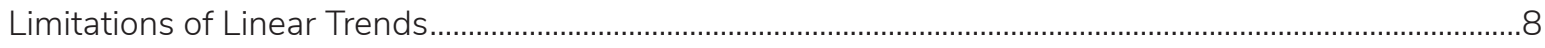

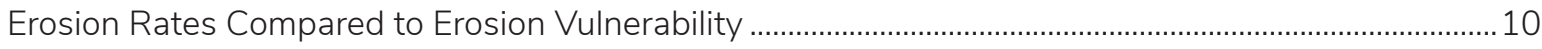

Regional Processes and Coastal Management ……………………………….......................................

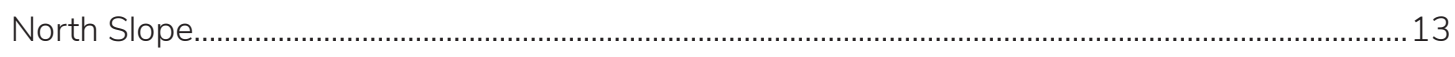

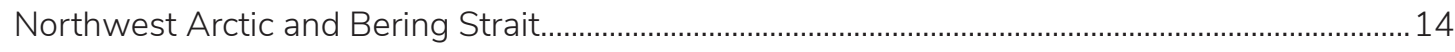

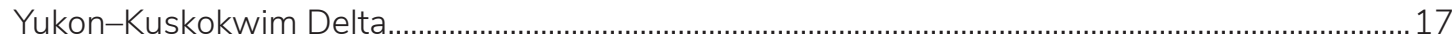

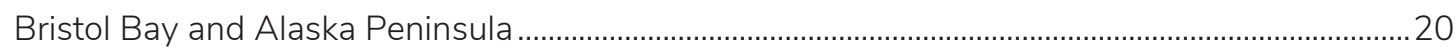

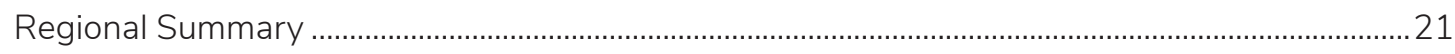

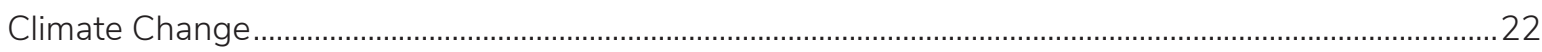

Community-Centered Hazard Mapping ……………....................................................................................2

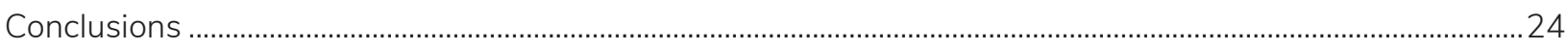

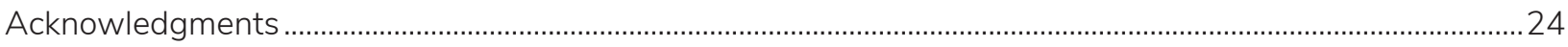

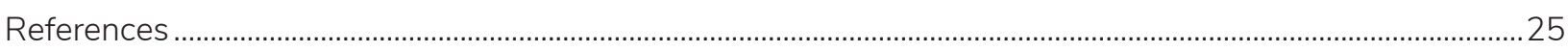

\section{Figures}

Figure 1. Communities subject to erosion .......................................................................................................................

Figure 2. Example of how the shoreline change analysis is used to compute the shoreline change envelope and the linear regression rate of shoreline change ..................................................................................

Figure 3. Example of map sheet for Kwigillingok, Alaska .......................................................................................

Figure 4. Maximum long-term rates of erosion measured at Alaska communities

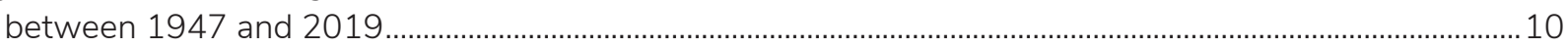

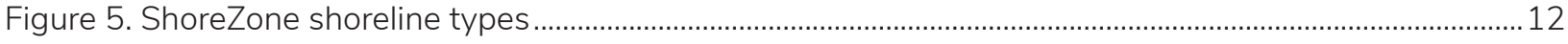

Figure 6. Erosion of ice-rich coastal bluffs at Utqiagvik during a coastal storm ..............................................14

Figure 7. Oblique photograph of the rock revetment at Kivalina......................................................................... 15

Figure 8. Shishmaref rock revetments shown by two different colors of rock .................................................... 15

Figure 9. Erosion south of the rock revetments at Shishmaref .................................................................................16

Figure 10. Oblique photograph of a portion of the rock revetment at Unalakleet ...............................................16

Figure 11. Oblique photograph of rubble rock revetment at St. Michael.............................................................. 16

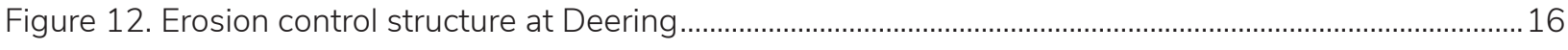

Figure 13. Unconsolidated gravel berm (used as a road) in front of the tank farm in Shaktoolik....................17

Figure 14. River bank at Alakanuk, where erosion has already undermined a road and other infrastructure. 
Figure 15. Erosion near the airstrip at Kwigillingok, which is also susceptible to permafrost degradation and flooding, which may lead to usteq .................................................................................... 17

Figure 16. Oblique photograph of Newtok .......................................................................................................... 18

Figure 17. Erosion at Nunam lqua near power poles and community water source intake pipe .....................18

Figure 18. Building overhanging river bank at Kotlik...........................................................................................19

Figure 19. Gabion basket revetment at Tununak .................................................................................................... 19

Figure 20. Erosion of coastal bluffs at Naknek........................................................................................................20

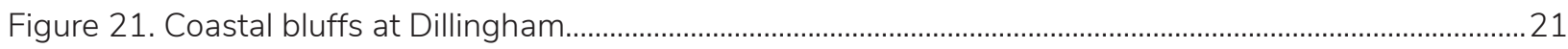

Figure 22. Erosion and subsequent drainage of Goldfish Lake at Port Heiden ...................................................21

\section{Tables}

Table 1. Shoreline and imagery datasets used for this report......................................................................................

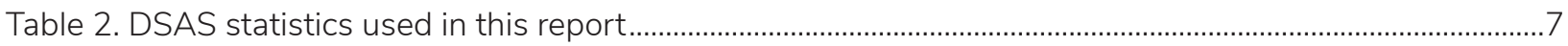

Table 3. The maximum rate of erosion, uncertainty in erosion rate, shoreline change rate type, and shoreline indicator at each community analyzed

\section{Appendix}

Table A1. Shoreline uncertainty values that remained constant for all communities analyzed here ...............30

Table A2. Shoreline uncertainty values computed for specific communities ........................................................30 



\section{CONVERSIONS}

1 meter $(\mathrm{m})=3.281$ feet $(\mathrm{ft})$

\section{ABBREVIATIONS}

AHAP = Alaska High-Altitude Aerial Photography

ANTHC = Alaska Native Tribal Health Consortium

ASPRS = American Society of Photogrammetry and Remote Sensing

$\mathrm{CVI}=$ coastal vulnerability index

DCRA = Division of Community \& Regional Affairs

DGGS = Division of Geological \& Geophysical Surveys

DHSEM = Division of Homeland Security \& Emergency Management

DLWD = Department of Labor \& Workforce Development

DOT\&PF = Department of Transportation \& Public Facilities

DSAS = Digital Shoreline Analysis System

$D S M=$ digital surface model

$\mathrm{EPR}=$ end point rate

FEMA = Federal Emergency Management Agency

GAO = General Accounting Office (pre-2004)/Government Accountability Office (currently)

GIS = geographic information system

GNSS = global navigation satellite system

GPS = global positioning system

$=$ high water line

IAWG = Immediate Action Working Group

ICC = Inuit Circumpolar Council

IPCC = International Panel on Climate Change

$\mathrm{LWI}=$ land-water interface

$\mathrm{MHW}=$ mean high water

NAVD88 $=$ North American Vertical Datum of 1988

NGS = National Geodetic Survey

NOAA = National Oceanic \& Atmospheric Administration

NPS $=$ National Park Service

NRCS = Natural Resource Conservation Service

$\mathrm{RMSE}_{r}=$ horizontal root-mean square error

UAF = University of Alaska Fairbanks

USACE $=$ U.S. Army Corps of Engineers

USGS $=$ U.S. Geological Survey

$\mathrm{VL}=$ vegetation line

$\mathrm{WLR}=$ weighted linear regression 


\title{
SHORELINE CHANGE AT ALASKA COASTAL COMMUNITIES
}

\author{
Jacquelyn R. Overbeck ${ }^{1}$, Richard M. Buzard ${ }^{1}$, Mark M. Turner ${ }^{1}$, Katie Y. Miller ${ }^{1}$, and Roberta J.T. Glenn ${ }^{1}$
}

\begin{abstract}
Many of Alaska's coastal communities are vulnerable to erosion, flooding, and permafrost degradation. However, few vulnerability assessment tools are available to the public that are complete or that utilize transparent, consistent, and quantitative methods at a scale needed for local planning. This report summarizes statewide analyses of long-term shoreline change at 48 Alaska communities. Shoreline datasets were compiled from previously published U.S. Geological Survey assessments for northern Alaska, as well as created from historical and recent aerial images by the Alaska Division of Geological \& Geophysical Surveys for western Alaska. Shorelines were analyzed to calculate rates of shoreline change every 82 feet ( 25 meters) along coastlines and tidally influenced river banks. In northern and western Alaska, 57 percent (27 of 48 total) of communities had erosion rates greater than 3.3 feet per year ( 1 meter per year) over the past 60 years. Maps of shoreline change and erosion rates are included here in a small map format for use by local community entities for planning and communication with state and federal agencies. Shoreline change rates alone do not describe community vulnerability, which may also depend on the location of infrastructure and the capacity of a community to respond to erosion, as well as other factors. Shoreline change rates were determined from historical data. Future rates of shoreline change may be influenced by coastal management and changes to environmental conditions that may result from climate change.
\end{abstract}

\section{BACKGROUND}

According to the U.S. General Accounting Office (GAO) (2003), 187 out of 213 (86 percent) Alaska Native villages are vulnerable to flooding and erosion to some extent. However, in the absence of measured shoreline change data, government reports (including GAO, 2003, 2009; Immediate Action Working Goup, 2008; U.S. Army Corps of Engineers [USACE], 2009; University of Alaska Fairbanks [UAF] and others, 2019) relied largely on anecdotal and now outdated sources, such as previous experience of engineers on staff and communities who self-reported their level of vulnerability. Although these reports highlighted that additional data and monitoring were necessary to improve reporting, limited progress has been made and subsequent reports (UAF and others, 2019) still primarily rely on the initial analysis of community vulnerability (e.g., USACE, 2009).

Alaska Native communities depend on state and federal resources for developing strategies and building infrastructure to respond to erosion. Consistent and quantifiable data are necessary to ensure that government resources are distributed appropriately among Alaska Native communities where the need for assistance far outweighs available resources. The Denali Commission (which funded UAF and others, 2019), recognized that quantifiable analyses were necessary to make better statewide assessments of environmental threats, and, as a result, included prototype scopes of work that could be followed for individual communities to determine

${ }^{1}$ Alaska Division of Geological \& Geophysical Surveys, 3354 College Rd., Fairbanks, Alaska 99709-3707. 
vulnerability and proceed with mitigation (UAF and others, 2019). The Denali Commission also funded development of this report, which fulfills a step in the prototype scope of work for erosion, to evaluate historical erosion rates. Previous efforts to evaluate erosion vulnerability for Alaska communities were largely not accomplished due to gaps in baseline data (Overbeck, 2018).

Alaska has nearly 40 percent of the tidally influenced shoreline in the U.S., yet much of the coast had remained unmapped at a resolution high enough to measure shoreline change until recent years. Between 2015 and 2019, the U.S. Geological Survey (USGS), the Alaska Division of Geological \& Geophysical Surveys (DGGS), and the National Oceanic \& Atmospheric Administration (NOAA) Office for Coastal Management made huge strides in mapping Alaska's coastline by employing photogrammetric techniques to develop modern and historical high-resolution orthorectified aerial imagery (Overbeck and others, 2016, 2017; Quantum Spatial, 2019), supplemented by lidar digital elevation data. Historical aerial images were orthorectified by Far North Geospatial, LLC. for continuous stretches of coastline, including aerial imagery collected by the Army (circa 195060s) and the USGS Alaska High-Altitude Photography (AHAP) effort (circa 1970-80s) and made available to the public as single-frame photographs (USGS, 2019).

Recent and historical orthoimagery provide critical baseline datasets for mapping shoreline change (Overbeck, 2018). Nationally, the USGS conducts assessments of historical rates of shoreline change using the Digital Shoreline Analysis System (DSAS; Himmelstoss and others, 2018). USGS shoreline change assessments have been completed continuously along coastlines for the contiguous U.S. and the Hawaiian Islands (Fletcher and others, 2012; Gibbs and Richmond, 2015; Gibbs, Snyder, and Richmond, 2019; Hapke and others, 2006; Hapke and Reid, 2007; Hapke and others, 2010; Kratzmann and others, 2013; Morton and others, 2004; Morton and Miller, 2005). The USGS shore- line analyses are not only continuous over very long stretches of coast but also localized to determine vulnerability approximately every $164 \mathrm{ft}(50 \mathrm{~m})$ along the coast, making them detailed enough for community-level decision making. USGS reports on shoreline change have been used in this report as the source of data for northern Alaska (Gibbs and Richmond, 2015; Gibbs, Snyder, and Richmond, 2019), while a DGGS assessment provided data for western Alaska. Coordination and collaboration among state and federal agencies resulted in high-quality coastal map data from past to present, from Kaktovik to Port Heiden, encompassing 48 Alaska communities, which was not possible for any single agency on its own.

\section{INTRODUCTION}

A shoreline defines a land-water interface at the coast; however, because of water level fluctuations due to tides, weather, and other factors, there are many definitions for shorelines (Boak and Turner, 2005; Gould and others, 2015). Shorelines can represent a specific vertical reference of an elevation on a beach (e.g., a tidal datum elevation such as mean sea level; NOAA, 2020) as well as a visual interpretation of a linear feature (e.g., a vegetation line that grows to the limit of saltwater influence; Gould and others, 2015). Shoreline change is the retreat or aggradation of a shoreline as a result of sediment erosion or accretion (Mangor and others, 2017). Shoreline change can occur because of changing sediment supply, oceanographic conditions, episodic storm events, terrestrial degradation through slope failure or permafrost thaw, and other nature- and human-driven processes. Shorelines are naturally very dynamic; however, when changes occur at or near infrastructure and land used for hunting or gathering subsistence resources, erosion can be disastrous (Alaska Deparment of Homeland Security \& Emergency Management [DHSEM], 2018).

DSAS is a tool used to measure shoreline change by computing the distance between shorelines through time at transects along the coast (Himmelstoss and others, 2018). The outputs of DSAS show how much shoreline change has 
occurred and the rate of shoreline change through time, which contributes directly to coastal vulnerability. Shoreline erosion rates are a common input to Coastal Vulnerability Indices (CVIs) around the world, with Alaska examples including Gorokhovich and Leiserowitz (2012) and the ShoreZone CVI (Harper, 2014), which used a simplified version of shoreline change rate terminology (e.g., erosional, stable, and accretional) as opposed to numerical rates.

In an effort to provide numerical shoreline change data to Alaskans for local decision making and assessments of vulnerability, the Alaska Division of Geological \& Geophysical Surveys (DGGS) has assimilated pre-existing shoreline change assessments (Gibbs and Richmond, 2015; Gibbs, Snyder, and Richmond, 2019) and conducted new shoreline change assessments on Alaska's western coast. This report summarizes the shoreline change assessments at communities on Alaska's northern and western coastlines, compares the results to existing government reporting, details typical regional mitigation responses to erosion, highlights potential impacts of climate change on shorelines, and explores how to develop hazard maps that directly address community needs. The report includes community map sheets that show shoreline change rates and historical shoreline extents relative to aerial imagery extending over community infrastructure. This report provides the most consistent and comprehensive quantitative assessment of shoreline change for Alaska communities to date, and serves as a communication tool for communities and state and federal agencies alike in understanding and responding to erosion.

\section{DATA}

DGGS acquired shoreline data from USGS assessments for northern Alaska (Gibbs and Richmond, 2015; Gibbs, Snyder, and Richmond, 2019) and carried out shoreline change assessments for western Alaska to determine shoreline change rates for 48 Alaska communities and to create shoreline change maps for 44 communities (where baseline data were available; fig. 1; table 1). Orthoimagery was collected on the North Slope in 2019 (Quantum

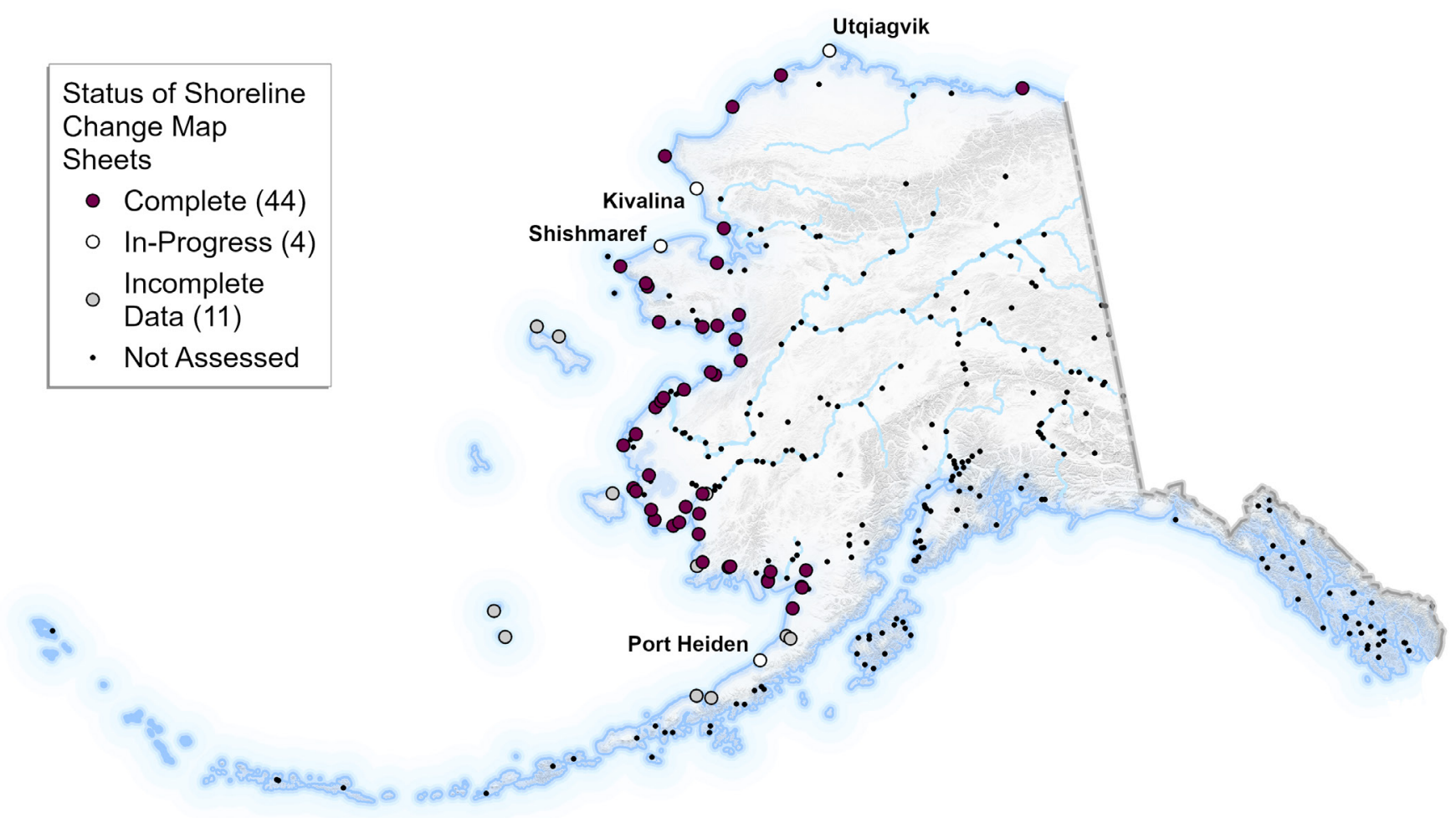

Figure 1. Communities subject to erosion that either are presented in this report (purple), will be released in a follow-up to this report (white), or did not have complete datasets to conduct a shoreline change analysis (gray). 
Table 1. Shoreline and imagery datasets used for this report*.

\begin{tabular}{|c|c|c|c|}
\hline Communities** & $\begin{array}{l}\text { Previous Shoreline } \\
\text { Dates and Source }\end{array}$ & $\begin{array}{l}\text { New Historical } \\
\text { Imagery Dates and } \\
\text { Source }\end{array}$ & $\begin{array}{l}\text { New Modern } \\
\text { Imagery Date and } \\
\text { Source }\end{array}$ \\
\hline Utqiagvik & $\begin{array}{l}\text { 1947, 2005, } 2010 \\
\text { (Gibbs and others, 2017) }\end{array}$ & none & $\begin{array}{l}2021 \\
\text { (planned) }\end{array}$ \\
\hline Kaktovik, Wainwright & $\begin{array}{l}\text { 1947/49, 2003/11 } \\
\text { (Gibbs and others, 2017) }\end{array}$ & $\begin{array}{l}\text { 2013/14 } \\
\text { (DCRA, 2019a) }\end{array}$ & $\begin{array}{l}2019 \\
\text { (Quantum Spatial, } \\
\text { 2019) }\end{array}$ \\
\hline $\begin{array}{l}\text { Deering, Kotzebue, Point Lay, Point } \\
\text { Hope }\end{array}$ & $\begin{array}{l}\text { 1949/50, 1978/82, 2016, } \\
2019 \\
\text { (Snyder and Gibbs, 2019) }\end{array}$ & none & none \\
\hline Kivalina, Shishmaref & $\begin{array}{l}\text { 1950/52, 1980/85, } \\
\text { 2003/04, } 2016 \\
\text { (Snyder and Gibbs, 2019) }\end{array}$ & none & $\begin{array}{l}\text { none (baseline } \\
\text { orthoimagery not } \\
\text { available for map } \\
\text { sheet) }\end{array}$ \\
\hline $\begin{array}{l}\text { Alakanuk, Brevig Mission, Chefornak, } \\
\text { Eek, Elim, Emmonak, Golovin, } \\
\text { Goodnews Bay, Hooper Bay, Kipnuk, } \\
\text { Kongiganak, Kotlik, Koyuk, Kwigillingok, } \\
\text { Napakiak, Newtok, Nome, Nunam lqua, } \\
\text { Quinhagak, St. Michael, Scammon Bay, } \\
\text { Shaktoolik, Stebbins, Teller, Toksook } \\
\text { Bay, Tuntutuliak, Tununak, Unalakleet, } \\
\text { Wales }\end{array}$ & none & $\begin{array}{l}\text { 1950-63, 1973-85, } \\
2002-13 \\
\text { Far North Geospatial } \\
\text { and DGGS } \\
\text { (DCRA, 2019a) }\end{array}$ & $\begin{array}{l}\text { 2015-16 } \\
\text { Fairbanks Fodar } \\
\text { (Overbeck and others, } \\
\text { 2016, 2017) }\end{array}$ \\
\hline $\begin{array}{l}\text { Levelock, Togiak, Twin Hills, } \\
\text { Dillingham, Clark's Point, Ekuk, Egegik, } \\
\text { Naknek, South Naknek }\end{array}$ & none & $\begin{array}{l}\text { 1951-52, 1980-83, } \\
2002 \\
\text { Far North Geospatial } \\
\text { and DGGS (DCRA, } \\
\text { 2019a) }\end{array}$ & $\begin{array}{l}2018 \\
\text { (Quantum Spatial, } \\
\text { 2019) }\end{array}$ \\
\hline Port Heiden & none & $\begin{array}{l}\text { TBD } \\
\text { Far North Geospatial } \\
\text { and DGGS } \\
\text { (DCRA, 2019a) }\end{array}$ & $\begin{array}{l}2019 \\
\text { (planned) }\end{array}$ \\
\hline
\end{tabular}

Spatial, 2019) and used to delineate more recent shorelines to add to and recompute the shoreline change assessment conducted by the USGS for certain communities (Gibbs and Richmond, 2015; table 1). A shoreline change assessment was completed for northwest Alaska more recently and did not require any updates (Gibbs, Snyder, and Richmond, 2019). For western Alaska, DGGS assessed the accuracy of and adjusted historical orthoimagery (delivered to DGGS by Far North Geospatial), delineated shorelines, and computed shoreline change rates. Fairbanks Fodar collected modern orthoimagery datasets in western Alaska (Overbeck and others, 2016, 2017), and Quantum Spatial collected data in southwestern Alaska (Quantum Spatial, 2019). Modern orthoimagery datasets achieved excellent horizontal precision (compared to GPS ground checkpoints) and were used to correct the historical datasets and determine their horizontal uncertainty. Some Alaska communities that experience coastal erosion were not analyzed here because baseline data were not available (fig. 1). For example, the baseline data used by the Kenai Peninsula Borough (Kenai Peninsula Borough, 2017) was not available to use in this report. 
Additional communities at risk to coastal erosion have not been assessed here. Please contact DGGS to learn more about shoreline change assessment data gaps at a particular community or to request a shoreline change assessment.

\section{METHODS}

The shoreline change analyses used to create community map sheets of shoreline change are described below. The analyses included assessing the quality of historical orthoimagery datasets, identifying and delineating shorelines in a Geographic Information System (GIS), computing shoreline position uncertainty, and computing historical shoreline change rates at transects cast along the coast using DSAS.

\section{Historical Imagery}

Historical imagery datasets were orthorectified by Far North Geospatial using Agisoft Photoscan over large geographic regions covering multiple hundreds of miles of shoreline. When compared to recent imagery datasets (Overbeck and others, 2016, 2017; Quantum Spatial, 2019) at individual communities, the horizontal root-mean square error, RMSE $\mathrm{r}_{\mathrm{r}}$ (American Society for Photogrammetry and Remote Sensing [ASPRS], 2014), of the historical datasets ranged from 0.6 to $65.6 \mathrm{ft}(0.17$ to $20 \mathrm{~m}$ ). To improve the horizontal accuracy of historical datasets, photo-identifiable points (which served as ground control and checkpoints) were identified in each community and used to conduct a first-order georeference of the already orthorectified imagery. The first-order georeference is a simple shift in the $\mathrm{x}$ and $\mathrm{y}$ direction of the imagery. The combination ground control/checkpoints were commonly difficult to identify due to the extreme differences in landscape as well as infrastructure over the period of time analyzed. Much of the infrastructure in rural communities today was not built before the early 1950s, when the first aerial imagery datasets were collected. Western Alaska has also been subject to vast environmental changes since the 1950's, including thawing permafrost resulting in thermokarst lakes draining or changing hydrology across landscapes, vegetation growth or decline, and frost heaving of surface rock features. For the communities analyzed, at least three points were used as ground control and checkpoints. The most common ground control/checkpoints used were $\mathrm{v}$-shaped vegetation patterns (for example, a treeline that came to a point) and distinct inland lake shorelines. A horizontal shift was performed on the imagery if the mean residual resulted in an RMSE $_{\mathrm{r}}$ greater than $8.2 \mathrm{ft}(2.5 \mathrm{~m})$ or the $\mathrm{RMSE}_{\mathrm{r}}$ could not be improved with shifting because the spread of the data was not consistent about the mean residual. The adjusted $\mathrm{RMSE}_{\mathrm{r}}$ ranged from 0.6 to $36 \mathrm{ft}(0.17$ to $11 \mathrm{~m})$ and averaged $7.4 \mathrm{ft}(2.3$ $\mathrm{m})$, which greatly improved the horizontal accuracy of the orthoimagery used for the shoreline change analyses.

\section{Shorelines}

A shoreline is a linear demarcation between land and water that can represent a visual feature or an elevation contour on the beach. Either type of shoreline (i.e., visual- or elevation-identified) can be delineated within a Geographic Information System (GIS) program (e.g., ArcGIS) based on source orthoimagery or elevation data. Shoreline data are created in the form of a vector (line) that represents the shoreline position at a particular time along a section of coast. For example, if multiple shoreline datasets are available, they can be compared visually to show how the shoreline has changed through time. The distance between shoreline vectors can also be measured to compute shoreline change distances and rates. The primary remote sensing datasets utilized for this work were orthoimagery, since not only does Alaska lack high-resolution elevation data along the coastline, but also tidal datums by which shoreline features are extracted from elevation data are not well established (although the contiguous U.S. has VDatum, there is no vertical reference datum conversion tool for Alaska).

Some shorelines or visible shoreline features (e.g., the visible wet/dry line in an image) are a 
good proxy for mean high water (MHW) tidal datum (Moore and others, 2006); however, variations in daily water levels may offset the visual shoreline from the MHW shoreline. Because there are not well-established tidal datum elevations along the coast of northern and western Alaska, the high water line (HWL) that represents the high tide and wave runup extent of the day, was used as a shoreline proxy for the modern imagery. Modern imagery is much higher in resolution and accuracy than historical datasets; in fact, for microtidal sand or gravel beaches with sporadic vegetation, the only visible feature in the historical imagery was the land-water interface (LWI) shoreline. The analysis directly compares LWI and HWL to compute shoreline change.

In mesotidal and macrotidal areas (vertical range of the tide is either between 6.5 and $13 \mathrm{ft}$ [2 and $4 \mathrm{~m}$ ] or above $13 \mathrm{ft}$ [ $4 \mathrm{~m}$ ], respectively), the HWL shoreline is difficult to interpret from orthoimagery; however, those coastal regions are also primarily river deltas or have coastal bluffs that have a visible vegetation line (VL). Thus, for regions with a distinct $\mathrm{VL}$, the $\mathrm{VL}$ was used to compute shoreline change. The tidal range on the outer coast of Alaska transitions from microtidal on the North Slope and in western Alaska to mesotidal between Hooper Bay and Nelson Island on the outer Yukon-Kuskokwim Delta. Moving south and east along the coast, tides then transition to macrotidal in areas of Bristol Bay. The shoreline proxies generally follow the geographic variation in tidal range, but are also referenced per community in the results.

\section{Shoreline Uncertainty}

Shoreline position uncertainty is a critical component of analyzing shoreline change because the uncertainty is used to show a range within which the shoreline has changed, given the accuracy of remote sensing datasets and the analysis method. Shoreline position uncertainty was computed for shorelines using the root sum of squares method for uncertainty of the data inputs:

$$
\begin{aligned}
& \mathrm{U}_{T}=\sqrt{\mathrm{U}_{o}^{2}+\mathrm{U}_{p}^{2}+\mathrm{U}_{d}^{2}} \text {, where } \\
& \mathrm{U}_{o}=\sqrt{\mathrm{U}_{o, \text { source }}^{2}+\mathrm{U}_{i}^{2}}, \text { orthorectification error, } \\
& \mathrm{U}_{o, \text { source }}=\text { horizontal uncertainty of recent imagery, } \\
& \mathrm{U}_{i}=\text { horizontal uncertainty of historical imagery, RMSE, } \\
& \mathrm{U}_{p}=\text { resolution error, and } \\
& \mathrm{U}_{d}=\text { digitizer error. }
\end{aligned}
$$

Orthorectification error $\left(\mathrm{U}_{0}\right)$ was computed as the root sum of squares between the horizontal uncertainty (RMSE; ASPRS, 2014) of the source imagery or ground control $\left(\mathrm{U}_{0, \text { source }}\right)$ and that of the orthorectified image $\left(\mathrm{U}_{i}\right)$. Resolution error $\left(\mathrm{U}_{d}\right)$ was the ground sample distance, or pixel size of the orthoimagery. Digitizer error $\left(\mathrm{U}_{d}\right)$ was computed for each individual who digitized shorelines - each digitizer delineated a section of coast from the lowest resolution orthoimagery three times; the average distance between the three shorelines was $U_{d}$.

\section{Shoreline Change}

DSAS is an ArcGIS tool developed by the USGS that uses delineated shorelines from various time periods as the input to analyze shoreline change (Himmelstoss and others, 2018). Shoreline change is measured at regular intervals along the coast at transects that are cast orthogonal to shorelines from a baseline (fig. 2A). At each transect, DSAS marks the position of the shoreline intersection and measures the distance between shorelines along the transect. DSAS then computes a suite of shoreline change statistics at each transect, including the distances between shorelines and rates of shoreline change. To compute a rate of shoreline change, a line is drawn through the position of shorelines through time, and the slope of the line represents the linear regression rate of change (fig. 2B). Other rates of shoreline change can also be computed, including the weighted linear regression (WLR; table 2). The WLR represents the shoreline change rate that takes into account the uncertainty in each shoreline position. The WLR was used to compute shoreline change rates at the communities where more than two shorelines were available. The end point rate (EPR; 
table 2) is the rate of change between the oldest and the newest shoreline. The EPR was used at communities where only two shorelines were available for the analysis, or in riverine environments that had episodic shoreline change. DSAS was used to cut the transects to the distance between the two furthest shorelines analyzed (i.e., the shoreline change envelope; fig. 2C). The community map sheets show the shoreline change envelope along the shoreline or river bank of a community, and are colored by the erosion rate (either WLR or EPR). For this report, transects were cast or recast (in the case of the USGS shorelines) to every $82 \mathrm{ft}(25 \mathrm{~m})$ along the coast.

The maximum rate of erosion is computed as the highest (most negative) rate of erosion at a particular transect near a community and is used throughout this document to compare erosion rates between communities.

\section{RESULTS}

Erosion has affected most communities on Alaska's northern and western coastline. Previous
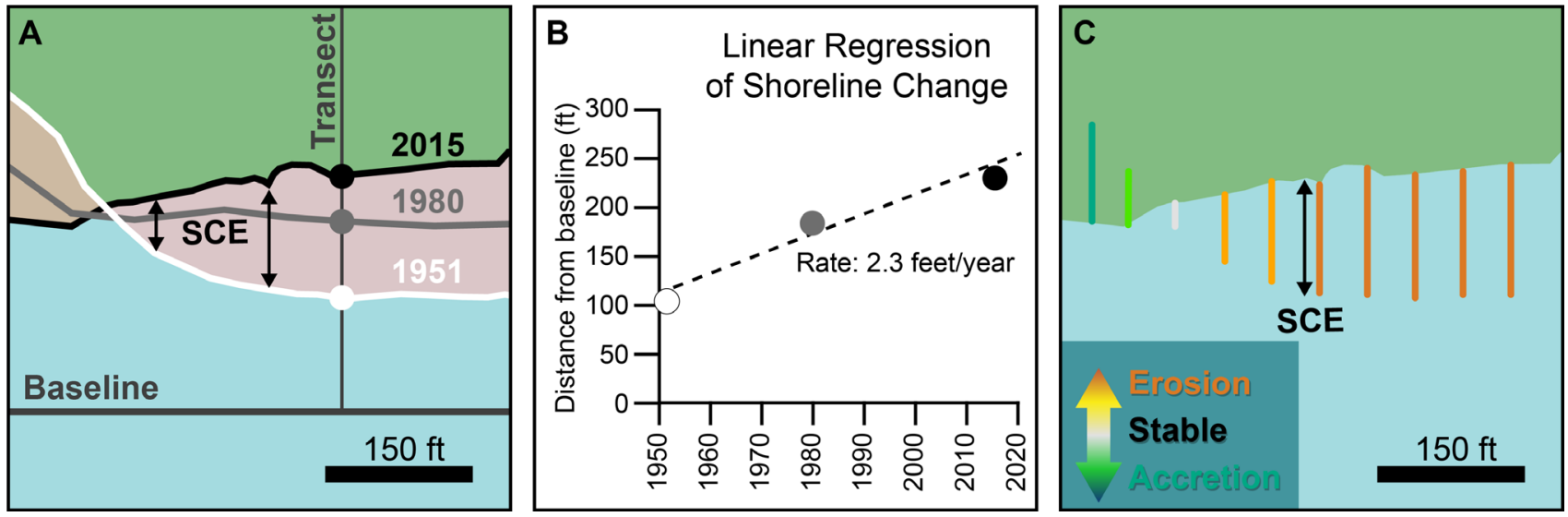

Figure 2. Example of how the shoreline change analysis is used to compute the shoreline change envelope (SCE) and the linear regression rate of shoreline change. A. Transects are cast across shorelines from a baseline to determine where the shorelines intersect the transect. B. The best fit line through the shoreline positions along the transect is used to compute the linear regression of shoreline change; the slope of the line is the shoreline change rate. C. Finally, the SCE, the line that represents the two farthest-apart shorelines is mapped to show how much the shoreline has changed, and colored to show shoreline change rate.

Table 2. DSAS statistics used in this report, with full descriptions (Himmelstoss and others, 2018).

\begin{tabular}{c|l|l} 
Acronym & Shoreline change statistic & \multicolumn{1}{c}{ Full description } \\
\hline EPR & End point rate & $\begin{array}{l}\text { The rate of shoreline change, calculated by dividing the distance of } \\
\text { shoreline movement by the time elapsed between the oldest and } \\
\text { the most recent shorelines. }\end{array}$ \\
\hline EPRunc & Uncertainty of the end point & $\begin{array}{l}\text { The spatial uncertainty of the EPR, computed by adding the root } \\
\text { sum of squares between the uncertainty of the oldest and the } \\
\text { most recent shorelines. }\end{array}$ \\
\hline WLR & Weighted linear regression & $\begin{array}{l}\text { The rate of shoreline change, calculated as the slope of the best-fit } \\
\text { line, weighted by uncertainties of the observed shoreline positions. }\end{array}$ \\
\hline WCI90 & $\begin{array}{l}\text { Standard error of the weighted } \\
\text { linear regression rate with a } 90 \\
\text { percent confidence interval }\end{array}$ & $\begin{array}{l}\text { The confidence interval of the weighted linear regression rate, } \\
\text { computed by multiplying the standard error of the weighted linear } \\
\text { regression rate by the two-tailed test statistic at the } 90 \text { percent } \\
\text { confidence interval. }\end{array}$ \\
\hline SCE & $\begin{array}{l}\text { Shoreline change envelope } \\
\text { The distance between the two shorelines furthest from each other } \\
\text { at a given transect. }\end{array}$
\end{tabular}


studies could not provide shoreline change rates at the community scale because of the low resolution and limited accuracy of datasets available at the time, such as from satellite imagery (Macander and others, 2014); such studies also lacked the capacity to conduct the work for such a large number of communities (USACE, 2009; UAF and others, 2019). This shoreline change assessment was made possible because of the coordinated and collaborative efforts of both state and federal agencies to collect baseline datasets, making this report the first consistent, community-centered, high-resolution, and quantifiable report of shoreline change for Alaska communities. In this report, shoreline change rates were measured at coastal and tidally influenced riverine communities in northern and western Alaska. The analysis was conducted near community infrastructure and areas used for subsistence and economic activities.

Maps of shoreline change show the shoreline envelope (this distance of the two farthest-apart shorelines) colored by shoreline change rate (example in fig. 3). Transects with erosion rates below $1 \mathrm{ft}$ per year were considered stable and were colored gray to keep the maps consistent with USGS methods (Gibbs and Richmond, 2015; Gibbs, Snyder, and Richmond, 2019). Gaps between transects do exist in areas, resulting from gaps in orthoimagery data, gaps in the shoreline data because of the location and extent of coastal river channels or lakes, and infrastructure impeding the shoreline such as docks, revetments, and roadways.

Among the communities analyzed here, the maximum rate of erosion ranged from 0.7 to 72.3 $\mathrm{ft}$ per year (0.2 to $22 \mathrm{~m}$; fig. 4; table 3). The highest rates of erosion (greater than $16.4 \mathrm{ft}$ per year $[5 \mathrm{~m}$ per year]) were measured at communities in very different geologic settings, including Newtok, Napakiak, Kaktovik, Port Heiden, and Dillingham. Although some communities had very rapid rates of erosion, only 57 percent of the communities analyzed here (27 of 48 ) had erosion rates greater than $3.3 \mathrm{ft}$ per year ( $1 \mathrm{~m}$ per year). The uncertainty of measured change rates averaged $1.2 \mathrm{ft}$ per year
(0.4 $\mathrm{m}$ per year), ranging between 0.1 and 18.7 $\mathrm{ft}$ per year (0.03 and $5.7 \mathrm{~m}$ per year), with the highest uncertainty at Newtok. In general, shoreline change rate uncertainty was driven by how accurately the linear regression model represented observed erosion, as well as by the magnitude of the erosion rate. At Newtok, for example, the erosion rate was very high $(72.3 \pm 18.7 \mathrm{ft}$ per year $[22 \pm 5.7$ $\mathrm{m}$ per year]), and the accompanying uncertainty was 26 percent the magnitude of the erosion rate. The average percent of uncertainty for all communities analyzed was 22 percent. Uncertainty at all communities reflected deviations from the linear trend; since some communities did not experience linear erosion, they had higher shoreline change rate uncertainty. Those communities may be more subject to episodic or nonlinear shoreline change.

\section{DISCUSSION}

Fifty-three percent of communities in northern and western Alaska eroded at a rate of more than $3.3 \mathrm{ft}$ per year ( $1 \mathrm{~m}$ per year) since the 1950s. However, there are communities where erosion rates alone do not show how vulnerable the community is to erosion. There are also communities that have experienced very rapid erosion but that have not been well represented by government reporting to date. The erosion rates reported here provide a quantitative context for erosion hazards along Alaska's coast. These rates should be compared to community infrastructure and land-use priorities before being used to determine community vulnerability.

\section{Limitations of Linear Trends}

The rates of shoreline change presented on the community map sheets are based on linear regression trends of shoreline change, primarily from four datasets collected circa the 1950s, 1980s, 2000s, and 2015-19, although at some locations there were fewer. Linear trends are useful for describing longterm geomorphic trends that take into account both active and passive mechanisms for change driven by underlying tectonism. However, they simplify very complex interactions of physical processes (including 


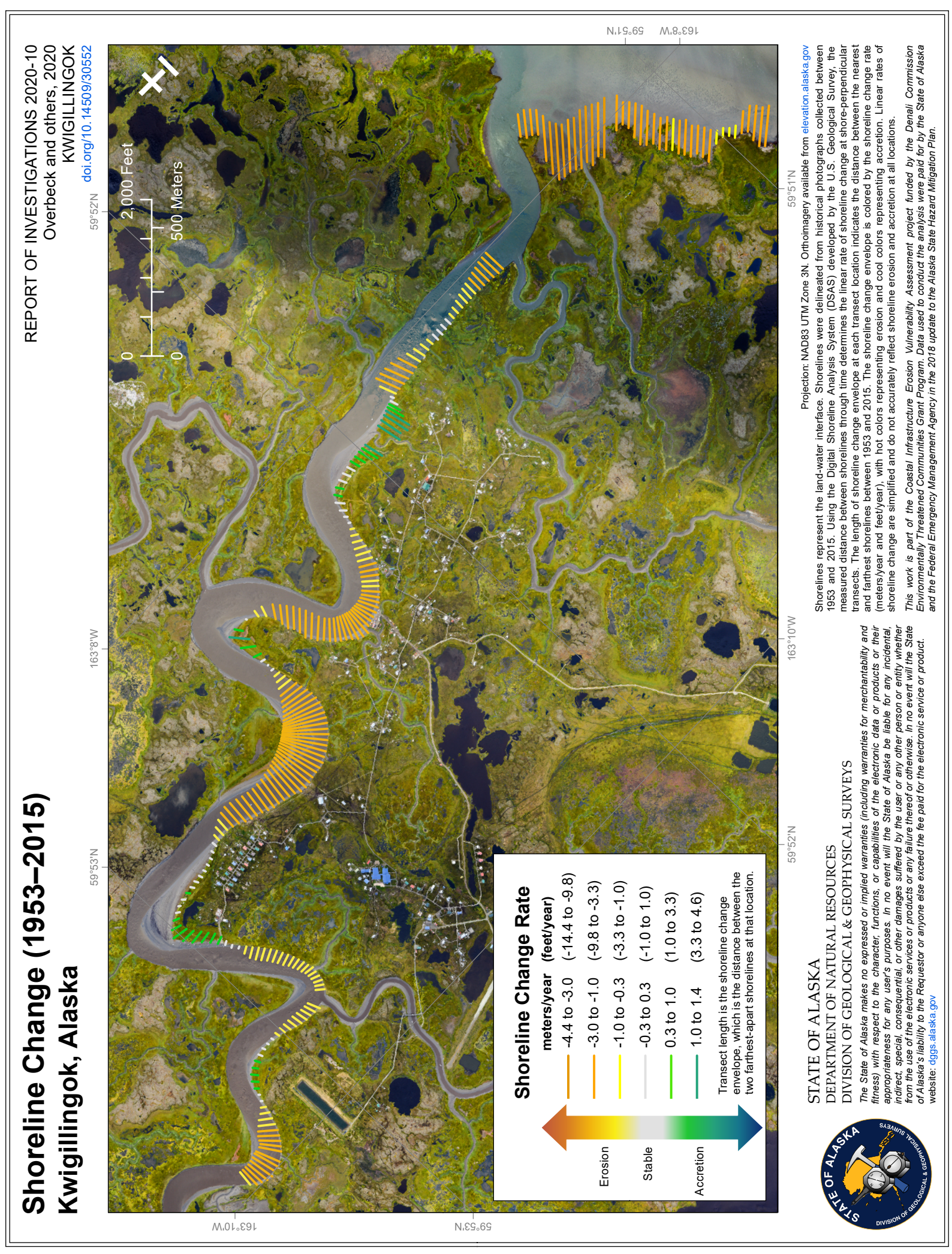

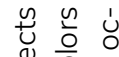

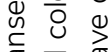

元

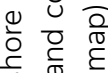

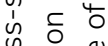

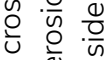

तै

ब. 들 을

든

요

जे $气$

苋 응 $\frac{3}{0}$

而苔苍兴

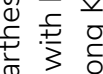

당

उ के

斻

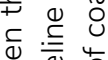

ब

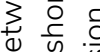

0 ᄂ

$\stackrel{8}{\triangle}$

त

웜

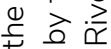

ज 앙

응 흥

음 으 을

$\sum$ 要

एं 웜

$\frac{\pi}{\pi}$ 崩

음 $\frac{0}{\pi}$

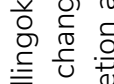

言

方言皆

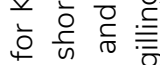

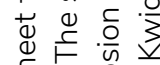

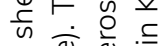

웡 응

$\varepsilon$ 응

$4 \geq 0$

웡

है है ब

யบ บ

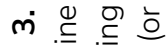

늠 웜 


\begin{tabular}{l} 
Maximum Rate of \\
Erosion (feet/year) \\
Custom \\
$0 \leq 72.8$ \\
$0 \leq 16.4$ \\
$\circ \leq 9.8$ \\
$\circ \leq 3.3$ \\
$\circ \leq 1.0$ \\
- Erosion Not \\
Assessed \\
\hline
\end{tabular}

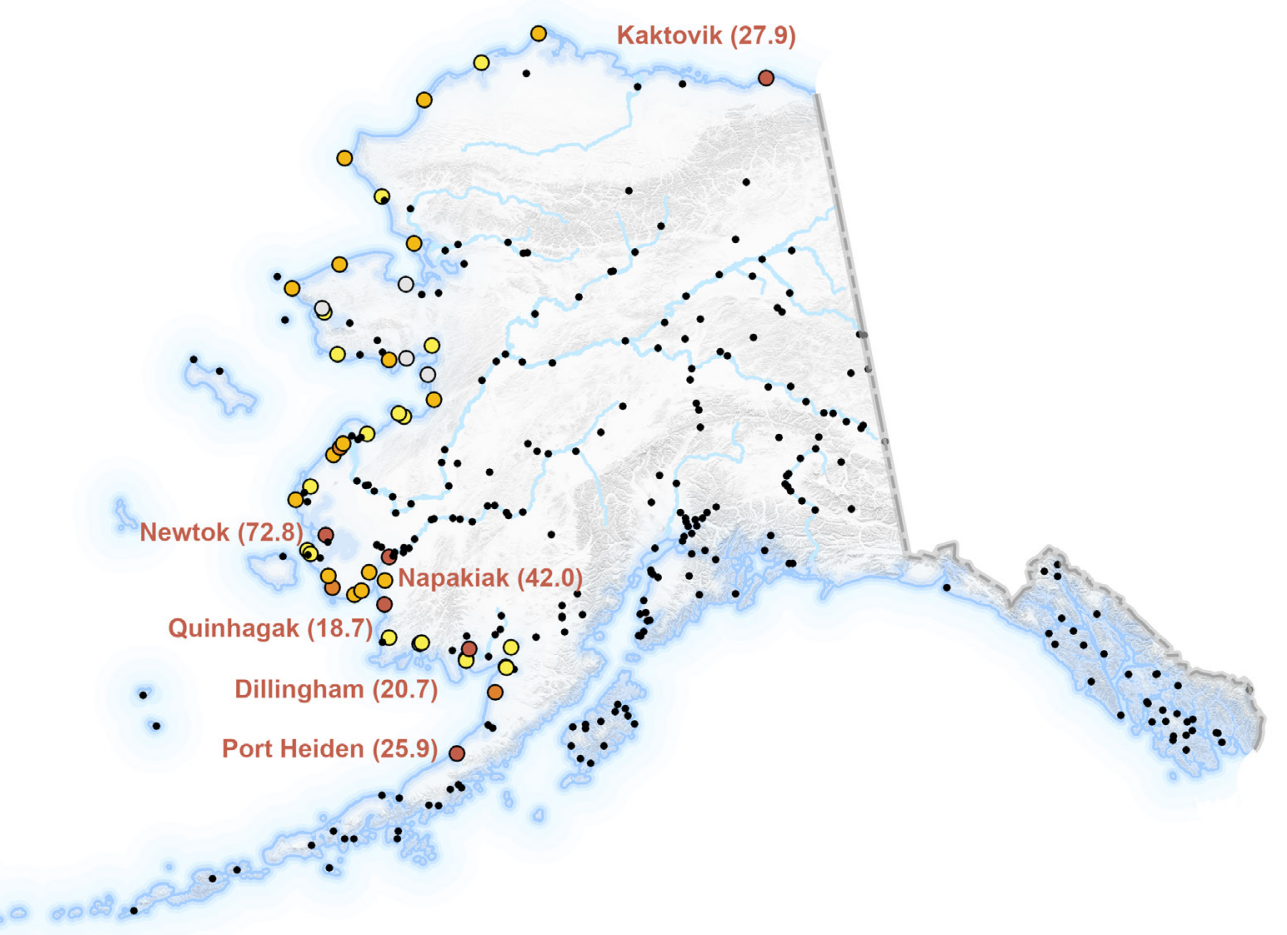

Figure 4. Maximum long-term rates of erosion measured at Alaska communities between 1947 and 2019. Results for some communities are still in progress while DGGS computes shoreline change rates; some communities do not have complete datasets to conduct a shoreline change analysis; and some communities' analyses have been completed but data are not available to the public.

tides, storm surges, waves, and currents) that result in erosion and accretion, and are not as representative of current conditions when there have been large changes to a coastal system, such as emplacement of shore protection structures. For example, some communities may have experienced less rapid erosion in recent years because of infrastructure built to mitigate the erosion, yet the long-term erosion rate took into account historical shoreline positions. Linear trends also underrepresent erosion if rates have recently increased (e.g., due to thawing permafrost or other processes such as sea ice decline). It is important to recognize these factors and limitations when interpreting the erosion rates presented in this report. Linear trends, however, provide an advantage over existing erosion assessments by quantifying historical erosion, as opposed to relying on written or anecdotal accounts alone. Future efforts to model shoreline change using process-based models that take into account physical processes would require additional data (e.g., nearshore bathymetry and water levels) at each community, which is not readily available across Alaska.

\section{Erosion Rates Compared to Erosion Vulnerability}

Erosion rates alone do not provide all the information necessary to determine whether a community is vulnerable to erosion or not. Vulnerability is broadly determined through evaluating the value of what is at risk to change, as well as the probability and severity of negative impacts. In the case of coastal erosion, vulnerability could be influenced by the distance of structures from an eroding shoreline, the erosion rate, or even a community's capacity to respond to erosion. Ultimately, the possibilities for determining a metric for vulnerability depend on the purpose for such a metric. For example, Harper (2014) developed a metric to compare coastal erosion vulnerability across the entire state of Alaska, which resulted in broad swaths of coast identified at the same vulnerability level. The Harper (2014) metric is not useful for regional or local community assess- 
Table 3. The maximum rate of erosion, uncertainty in erosion rate, shoreline change rate type, and shoreline indicator at each community analyzed. WLR = weighted line regression; HWL = high water level; LWI = land-water interface; EPR = end point rate; $\mathrm{VL}=$ vegetation line.

\begin{tabular}{|c|c|c|c|c|c|c|c|c|}
\hline $\begin{array}{l}\text { Erosion Rate } \\
\text { Class }\end{array}$ & Community & $\begin{array}{c}\text { Max. Rate } \\
\text { of Erosion } \\
\text { (ft/yr) }\end{array}$ & $\begin{array}{l}\text { Average } \\
\text { Uncertainty, } \\
\text { WCI90 or } \\
\text { EPRunc } \\
\text { (ft/yr) }\end{array}$ & $\begin{array}{c}\text { Max. Rate } \\
\text { of Erosion } \\
(\mathrm{m} / \mathrm{yr})\end{array}$ & $\begin{array}{l}\text { Average } \\
\text { Uncertainty } \\
\text { WCI90 or } \\
\text { EPRunc (m/yr) }\end{array}$ & Rate Type & $\begin{array}{l}\text { Shoreline } \\
\text { Indicator }\end{array}$ & Time Range \\
\hline \multirow{6}{*}{$\begin{array}{l}>16.4 \mathrm{ft} / \mathrm{yr} \\
(5 \mathrm{~m} / \mathrm{yr})\end{array}$} & Newtok & -72.8 & 18.7 & -22.2 & 5.7 & WLR & $\mathrm{VL}$ & 1951-2015 \\
\hline & Napakiak & -42.0 & 0.3 & -12.8 & 0.1 & EPR & $\mathrm{VL}$ & $1952-2015$ \\
\hline & Kaktovik & -27.9 & 5.9 & -8.5 & 1.8 & WLR & HWL/LWI & 1947-2019 \\
\hline & Port Heiden & -25.9 & 0.3 & -7.9 & 0.1 & EPR & $\mathrm{VL}$ & 1957-2013 \\
\hline & Dillingham & -20.7 & 3.0 & -6.3 & 0.9 & WLR & $\mathrm{VL}$ & $1952-2018$ \\
\hline & Quinhagak & -18.7 & 0.3 & -5.7 & 0.1 & EPR & $\mathrm{VL}$ & $1952-2016$ \\
\hline \multirow{3}{*}{$\begin{array}{l}>9.8 \mathrm{ft} / \mathrm{yr} \\
(3 \mathrm{~m} / \mathrm{yr})\end{array}$} & Alakanuk & -13.8 & 0.1 & -4.2 & 0.0 & EPR & $\mathrm{VL}$ & 1951-2015 \\
\hline & Egegik & -13.1 & 0.1 & -4.0 & 0.0 & EPR & $\mathrm{VL}$ & 1951-2018 \\
\hline & Kipnuk & -9.8 & 0.7 & -3.0 & 0.2 & WLR & $\mathrm{VL}$ & $1952-2015$ \\
\hline \multirow{18}{*}{$\begin{array}{l}>3.3 \mathrm{ft} / \mathrm{yr} \\
(1 \mathrm{~m} / \mathrm{yr})\end{array}$} & Kwigillingok & -9.7 & 1.5 & -3.0 & 0.5 & WLR & $\mathrm{VL}$ & $1953-2015$ \\
\hline & Clark's Point & -8.5 & 0.3 & -2.6 & 0.1 & EPR & $\mathrm{VL}$ & 1951-2018 \\
\hline & Point Hope & -7.9 & 0.7 & -2.4 & 0.2 & EPR & HWL/LWI & 1950-2019 \\
\hline & Shishmaref & -7.5 & 2.0 & -2.3 & 0.6 & WLR & HWL/LWI & 1950-2016 \\
\hline & Emmonak & -7.5 & 0.1 & -2.3 & 0.0 & EPR & $\mathrm{VL}$ & 1950-2016 \\
\hline & Naknek & -6.9 & 1.3 & -2.1 & 0.4 & WLR & $\mathrm{VL}$ & $1951-2018$ \\
\hline & Nunam lqua & -6.9 & 1.3 & -2.1 & 0.4 & WLR & $\mathrm{VL}$ & 1951-2015 \\
\hline & Chefornak & -6.6 & 1.0 & -2.0 & 0.3 & WLR & $\mathrm{VL}$ & $1952-2015$ \\
\hline & Point Lay & -5.9 & 0.7 & -1.8 & 0.2 & EPR & HWL/LWI & 1949-2016 \\
\hline & Golovin & -5.6 & 1.0 & -1.7 & 0.3 & WLR & HWL/LWI & 1951-2019 \\
\hline & Wales & -5.6 & 0.3 & -1.7 & 0.1 & EPR & HWL/LWI & 1950-2012 \\
\hline & Eek & -4.9 & 1.0 & -1.5 & 0.3 & WLR & $\mathrm{VL}$ & $1953-2015$ \\
\hline & Hooper Bay & -4.6 & 0.3 & -1.4 & 0.1 & EPR & $\mathrm{VL}$ & 1951-2015 \\
\hline & Unalakleet & -4.6 & 1.3 & -1.4 & 0.4 & WLR & $\mathrm{VL}$ & 1951-2015 \\
\hline & Tuntutuliak & -4.3 & 0.7 & -1.3 & 0.2 & WLR & $\mathrm{VL}$ & $1952-2015$ \\
\hline & Kotzebue & -4.3 & 1.0 & -1.3 & 0.3 & WLR & HWL/LWI & 1950-2016 \\
\hline & Kongiganak & -3.9 & 0.7 & -1.2 & 0.2 & WLR & $\mathrm{VL}$ & 1952-2015 \\
\hline & Utqiagvik & -3.6 & 1.0 & -1.1 & 0.3 & EPR & HWL/LWI & $1947-2010$ \\
\hline \multirow{16}{*}{$\begin{array}{l}>1.0 \mathrm{ft} / \mathrm{yr} \\
(0.3 \mathrm{~m} / \mathrm{yr})\end{array}$} & Koyuk & -3.3 & 0.1 & -1.0 & 0.0 & EPR & $\mathrm{VL}$ & $1950-2015$ \\
\hline & Levelock & -3.3 & 1.0 & -1.0 & 0.3 & WLR & $\mathrm{VL}$ & $1951-2018$ \\
\hline & Scammon Bay & -3.0 & 0.7 & -0.9 & 0.2 & EPR & $\mathrm{VL}$ & $2007-2015$ \\
\hline & Twin Hills & -3.0 & 1.3 & -0.9 & 0.4 & WLR & $\mathrm{VL}$ & $1952-2018$ \\
\hline & Teller & -2.6 & 1.0 & -0.8 & 0.3 & WLR & HWL/LWI & 1950-2015 \\
\hline & Wainwright & -2.6 & 0.7 & -0.8 & 0.2 & EPR & HWL/LWI & 1949-2019 \\
\hline & Toksook Bay & -2.6 & 0.1 & -0.8 & 0.0 & EPR & $\mathrm{VL}$ & 1955-2015 \\
\hline & Kotlik & -2.3 & 1.0 & -0.7 & 0.3 & WLR & $\mathrm{VL}$ & 1951-2015 \\
\hline & Nome & -2.3 & 0.3 & -0.7 & 0.1 & EPR & HWL/LWI & 1951-2015 \\
\hline & St. Michael & -2.3 & 0.3 & -0.7 & 0.1 & EPR & HWL/LWI & 1951-2015 \\
\hline & South Naknek & -2.0 & 0.7 & -0.6 & 0.2 & WLR & $\mathrm{VL}$ & $1951-2018$ \\
\hline & Goodnews Bay & -1.6 & 0.7 & -0.5 & 0.2 & WLR & HWL/LWI & $1957-2016$ \\
\hline & Ekuk & -1.6 & 0.3 & -0.5 & 0.1 & EPR & $\mathrm{VL}$ & 1951-2018 \\
\hline & Stebbins & -1.6 & 0.3 & -0.5 & 0.1 & EPR & HWL/LWI & $1951-2015$ \\
\hline & Tununak & -1.3 & 0.1 & -0.4 & 0.0 & EPR & $\mathrm{VL}$ & 1955-2015 \\
\hline & Kivalina & -1.3 & 0.3 & -0.4 & 0.1 & EPR & HWL/LWI & $1952-2016$ \\
\hline \multirow{5}{*}{$\begin{array}{l}<1.0 \mathrm{ft} / \mathrm{yr} \\
(0.3 \mathrm{~m} / \mathrm{yr})\end{array}$} & Deering & -1.0 & 1.0 & -0.3 & 0.3 & 0.3 & HWL/LWI & $1978-2016$ \\
\hline & Shaktoolik & -1.0 & 0.1 & -0.3 & 0.0 & 0.0 & HWL/LWI & $1950-2015$ \\
\hline & Brevig Mission & -0.7 & 0.3 & -0.2 & 0.1 & 0.1 & HWL/LWI & 1950-2015 \\
\hline & Elim & -0.7 & 0.1 & -0.2 & 0.0 & 0.0 & HWL/LWI & 1951-2015 \\
\hline & Togiak & -0.3 & 1.3 & -0.1 & 0.4 & 0.4 & $\mathrm{VL}$ & 1953-2018 \\
\hline
\end{tabular}


ments of vulnerability that are needed to prioritize different structures within a community that may be more or less at risk. Vulnerability is also not static; it changes through time as a community grows or declines in population, builds new infrastructure, takes measures to mitigate erosion, or even shifts cultural values. This is why remapping communities at regular intervals is necessary for short- and longterm decision making. The time interval between mapping efforts depends on the rate of erosion and the coastal processes driving erosion. For rapidly eroding coastlines, annual remapping or continuous localized monitoring may be necessary to manage the impacts of erosion. However, for more stable coastlines, remapping may not be necessary for years or decades at a time. For coastlines impacted by storm surge flooding, remapping may be necessary after storm events.

The interrelated social, environmental, and cultural issues surrounding erosion also call for interdisciplinary advancements in the general understanding of vulnerability. This is particularly relevant in Alaska, where subsistence hunting and gathering activities are central to culture and survival for Indigenous people (GAO, 2009). More work is needed to determine what vulnerability means to Alaska communities, and a vital and feasible first step is measuring historical shoreline change.

Since there are so many communities in Alaska facing erosion hazards, and since communities look primarily to state and federal resources to address erosion issues, there is a need for understanding vulnerability at each community consistently for the entire state. In the absence of measured shoreline change information, previous reporting (GAO, 2003; GAO, 2009; USACE 2009; UAF and others, 2019) has underreported erosion threats at certain communities with very high erosion rates. The results of this report will help identify additional communities at risk to erosion that were not previously identified. However, this report does not provide a full assessment of vulnerability because the risk has not yet been associated with infrastructure or community values. This report encompasses only 48 communities, whereas previous studies found 187 communities vulnerable to erosion (GAO, 2009). Improvements in collecting baseline data are necessary at the remaining communities in order to compute shoreline or river change rates.

\section{Regional Processes and Coastal Management}

Alaska is so diverse in geology, ecology, culture, and governance along its coastline that, inevitably,
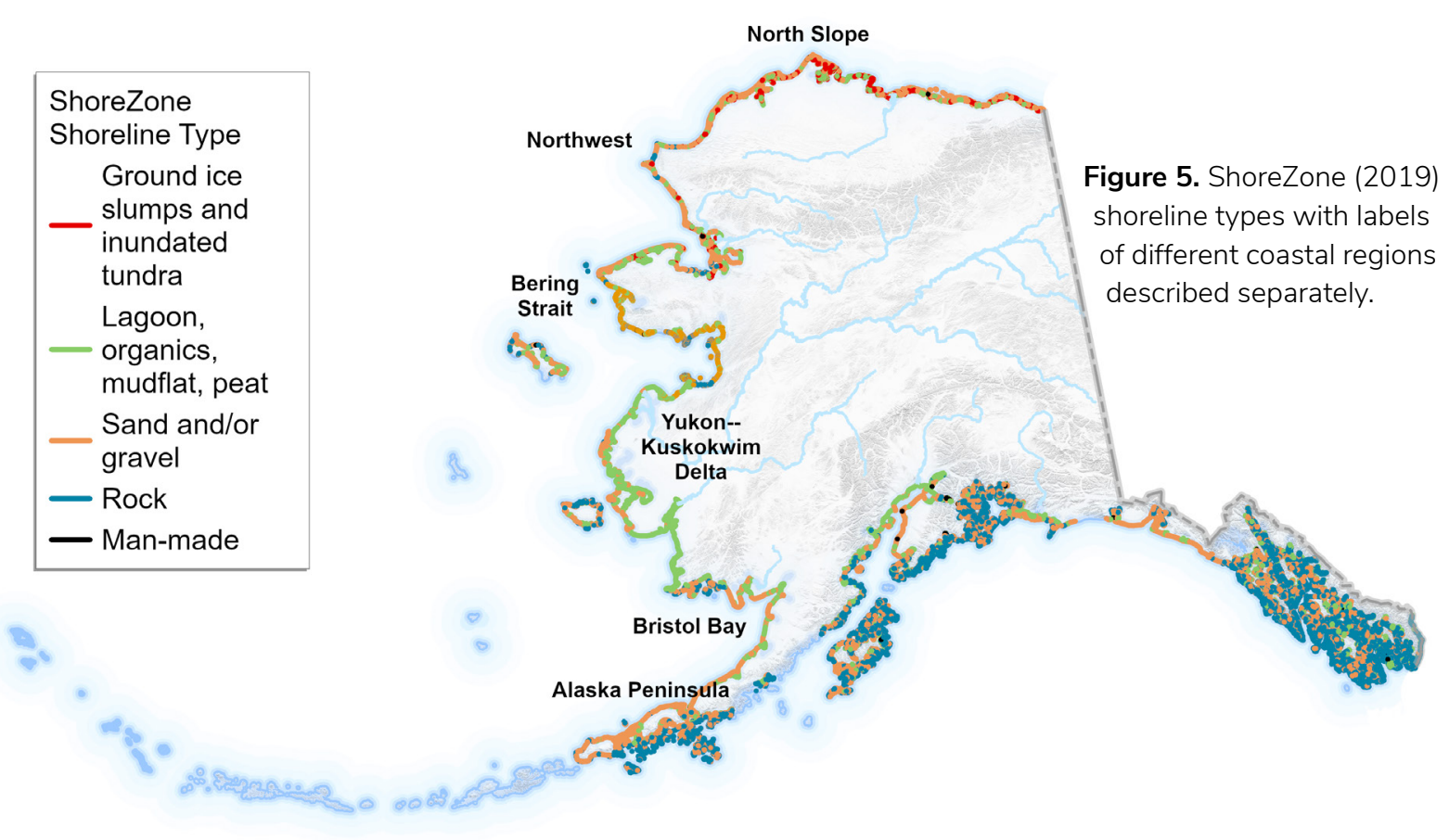
coastal processes and management strategies have also varied. Different zones of the coastline have been grouped here (i.e., North Slope, Northwest Arctic, Bering Strait, Yukon-Kuskokwim Delta, Bristol Bay, and Alaska Peninsula; fig. 5) to aid in discussion regarding the drivers of shoreline change and the responses to erosion.

Across all regions of Alaska the coastline is very diverse, ranging from micro- to macrotidal, and including areas of inundated tundra, vegetated peat, mudflats, lagoons fronted by barrier islands, inlets, bays, beaches, bluffs, or cliffs (Gorokhovich and Leiserowiz, 2012; ShoreZone, 2019; fig. 5). The coast is composed of materials ranging from ice to organics to mud, sand, gravel, or rock (ShoreZone, 2019; fig. 5). Northern and western Alaska are on passive tectonic margins, which results in low relief compared to the mountainous active margins of the Aleutians, southcentral Alaska, and southeast Alaska. Northern and western Alaska also experience relative sea level stability compared to sea level decline or rise in other regions (Sweet and others, 2017). The Alaska coastline has regions with similar morphology to most other U.S. coastlines-for example, volcanic islands of the Aleutians similar to Hawaii, lithified coastal bluffs in Bristol Bay and on the Kenai Peninsula similar to California, sandy barrier islands on the North Slope similar to the Outer Banks of North Carolina, and rocky cliffs in southeast Alaska similar to Maine. Alaska is different, however, in that the coastline is affected by periglacial processes and in many regions composed of permafrost. In general, permafrost is coldest and most continuous along the North Slope and in northwest Alaska, and becomes more discontinuous, with temperatures closer to the freezing point (i.e., $32^{\circ} \mathrm{F}$, or $0^{\circ} \mathrm{C}$ ), moving south toward the Yukon-Kuskokwim Delta and Bristol Bay (Jorgenson and others, 2008). Sea ice forms in the Beaufort, Chukchi, and Bering seas each fall and winter. The sea ice extent moves south as air temperatures drop, extending out to the Pribilof Islands in the middle of the Bering Sea and along the coast to Bristol Bay (in some years); the sea ice then recedes back north through spring and summer, opening up the coast to water and waves all along the North Slope. Since the coast of Alaska formed under periglacial processes, major changes to ocean and air temperatures that result in less sea ice and thawed permafrost-because of climate change_could also impact coastal morphology.

\section{North Slope}

Most academic and government research regarding coastal erosion in Alaska has been focused on Alaska's North Slope and the Canadian Arctic, with studies of the mechanics and drivers of erosion of ice-rich coastal bluff failure through block collapse (e.g., Barnhart and others, 2014; Barnhart, Overeem, and Anderson, 2014; Jones and others, 2008, 2009, 2013, 2018; Mars and Houseknecht, 2007; Thomas and others, 2020; Wobus and others, 2011). Although there are regions along the North Slope coast where erosion is occurring faster than in most other parts of the world due to block collapse of permafrost coastlines (Gibbs and Richmond, 2015), those regions are primarily uninhabited or host infrastructure operated by oil industry rather than communities. Although block collapse of coastal permafrost does occur near the outer margins of some community infrastructure, the five communities that do reside along the North Slope coast of Alaska are also fronted by gravel and sand spits or barrier islands. In addition to permafrost degradation, North Slope communities are vulnerable to erosion due to coastal storms that occur during ice-free ocean conditions (fig. 6). Coastal storms on the North Slope develop in the Arctic, the magnitude of storm surge and waves depends on the extent of the northern sea ice edge throughout summer and fall, which controls the span of open water (i.e., fetch) that storms are able to develop over.

The North Slope Borough actively manages erosion at the North Slope community hub, Utqiagvik, through management of a sand berm that is built up before and during high water and wave events. Although these might be considered 


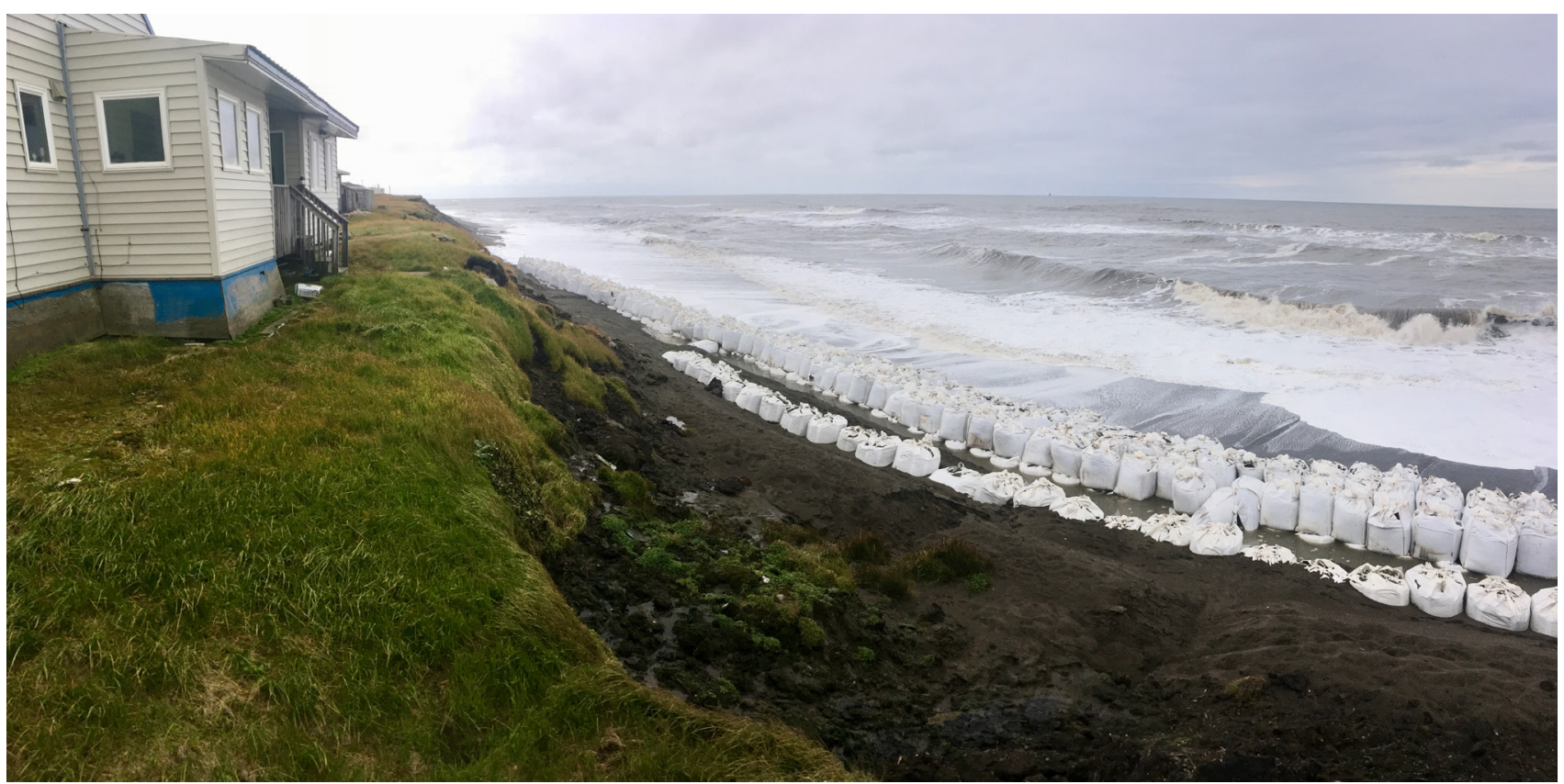

Figure 6. Erosion of ice-rich coastal bluffs at Utqiagvik during a coastal storm. Photo taken August 2019. Sandbags have been placed at the base of the coastal bluff to mitigate erosion.

"small-scale" storm events (e.g., wind and surge that might not reach hurricane or Nor'easter categorization levels), they can still result in flooding and erosion at the community. A rock revetment was built along $500 \mathrm{ft}(153 \mathrm{~m})$ of shoreline at the community of Wainwright in 2013 to halt erosion in front of approximately 25 percent of the community's critical infrastructure on the coast; however, the remainder of the coastline is still at risk to erosion (Umiaq and Olgoonik Development, LLC, 2014). The airport at Point Hope is currently undergoing re-alignment to avoid erosion of the end of the runway (Department of Transportation \& Public Facilities [DOT\&PF], 2019). The remaining communities on the North Slope coast (Point Lay and Kaktovik) have much of their infrastructure far enough away from eroding shorelines that mitigation measures have not yet taken place, but such measures may be necessary in the future.

\section{Northwest Arctic and Bering Strait}

Moving south through northwest Alaska and the Bering Strait region, many coastal communities have been built on mixed sand and gravel spits and barrier islands, making them vulnerable to erosion from coastal storms (for example, fig. 7, which shows sediment deposited in front of the Kivalina rock revetment after construction). Coastal storms (extratropical cyclones) develop either over the Russia mainland and build energy over the Bering Sea, or over the northwest Arctic and build over the Chukchi Sea. Coastal storms typically track up the coast (from south to north) but can also directly impact from the west. As storms move toward the coast, storm surge builds. In the comparatively narrow embayments of Norton Sound and Kotzebue Sound, storm surge is enhanced, resulting in higher storm elevations at the heads of the sounds. Although erosion during a single coastal storm can be alarming, the long-term trends of shoreline change for most communities in the northwest and Bering Strait region are stable to slowly erosional.

Coastal communities in this region have conducted erosion mitigation primarily through building (or emplacing) structural solutions to erosion, flooding, or a combination of both, which has resulted in stabilized shorelines. Coastal protection structures, such as rock or concrete revetments, 


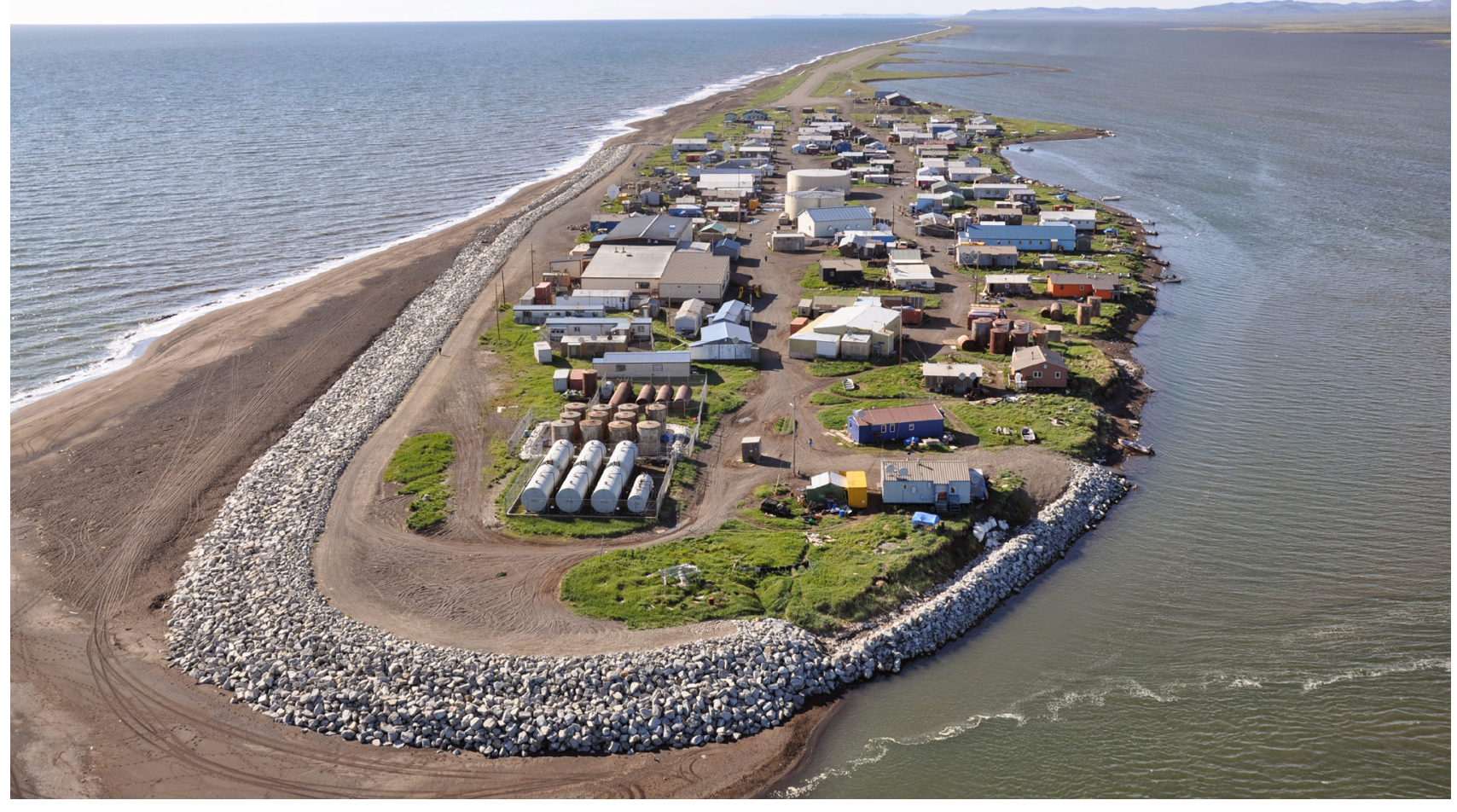

Figure 7. Oblique photograph of the rock revetment at Kivalina, taken July 2012 (ShoreZone, 2019).

can effectively reduce the rate of erosion over the section of coast on which they are built. This is the case at Shishmaref, where historical erosion of the barrier island was very rapid. However, in recent years, portions of the island have been protected by multiple rock revetments (fig. 8). Although erosion along the rock revetments was effectively mitigated after construction, these large structures are cost prohibitive; as a result, the revetments do not extend along the entire length of the island, meaning rapid erosion still occurs south of the revetments at the community's airport, landfill, frontage road, and subsistence sites (fig. 9). Hardening the shoreline can also have negative impacts on adjacent areas that may become sediment starved because of the loss of sediment from the previously eroding coastline, or where edge effects result in greater focus of wave energy on the ends of the hardened structure, resulting in erosion on either side of a revetment (Griggs, 2005). Any shoreline revetment built to halt erosion will eventually result in the loss of access to the beach and, over time, the erosion of

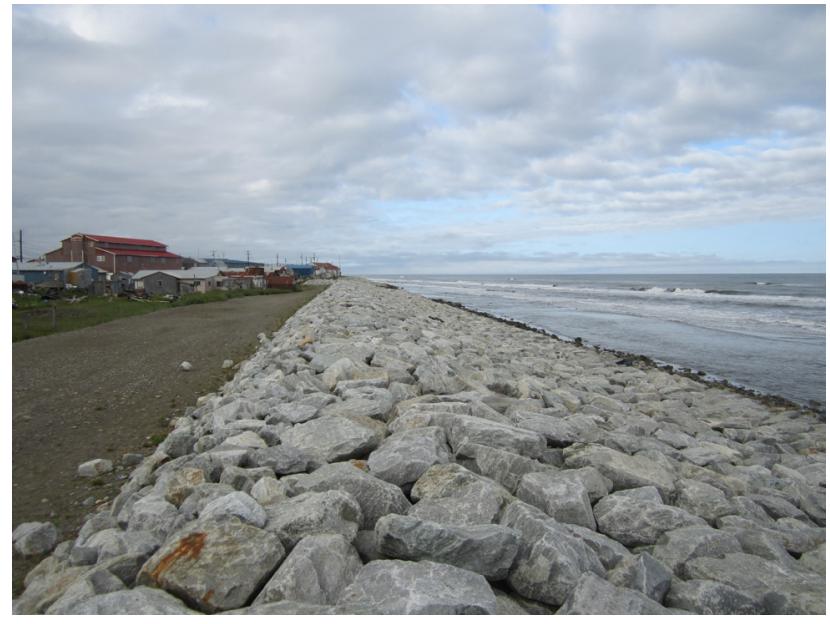

Figure 8. Shishmaref rock revetments. Photo taken August 2017.

the beach fronting the revetment (Griggs, 2005; Mangor and others, 2017).

Rock revetments utilize large boulder-sized rocks, which can be displaced by waves and rock scour during large storm events and thus require investments in maintenance if they are to protect in 

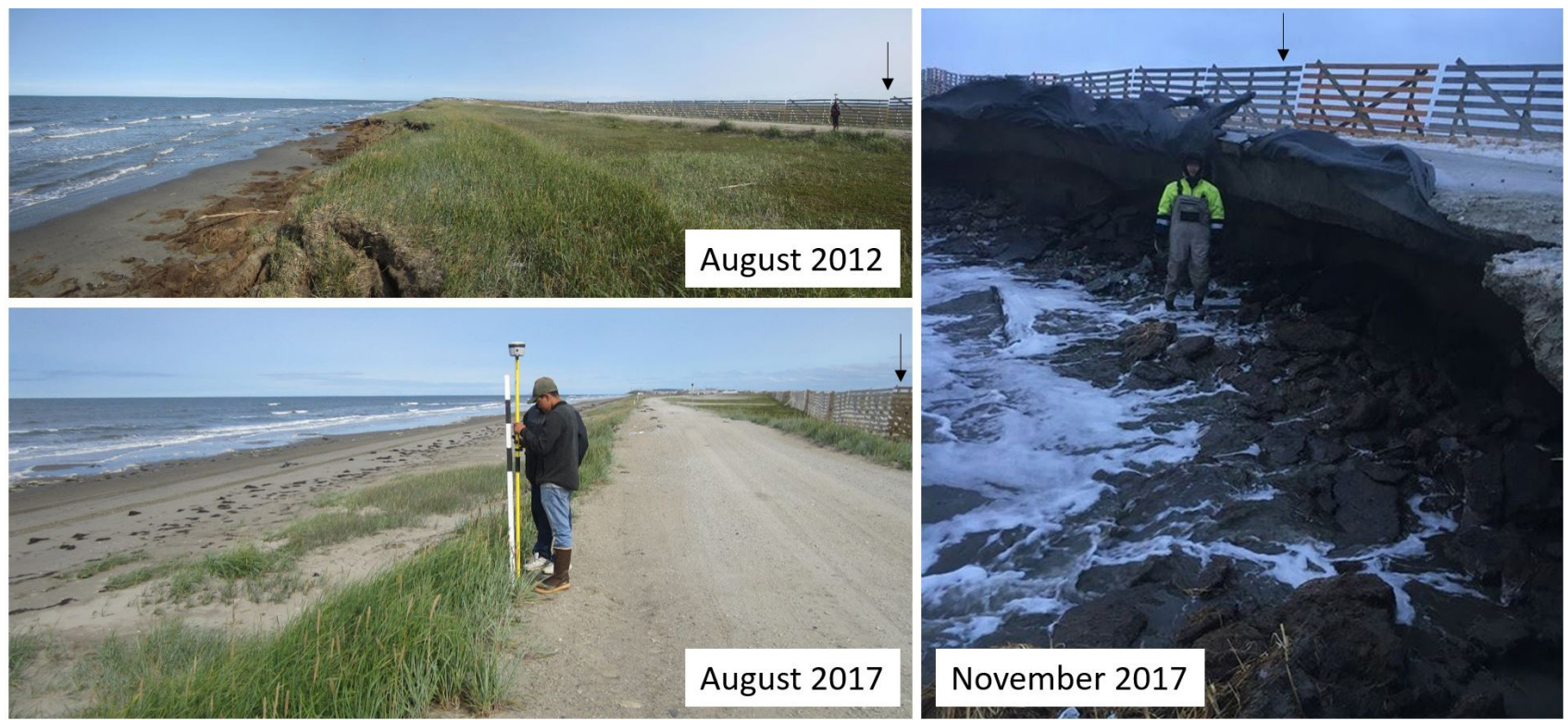

Figure 9. Erosion south of the rock revetments at Shishmaref between August 2012 and August 2017, as well as after a storm in November 2017 (photo provided by the Native Village of Shishmaref), with a stationary snow fence for spatial reference.

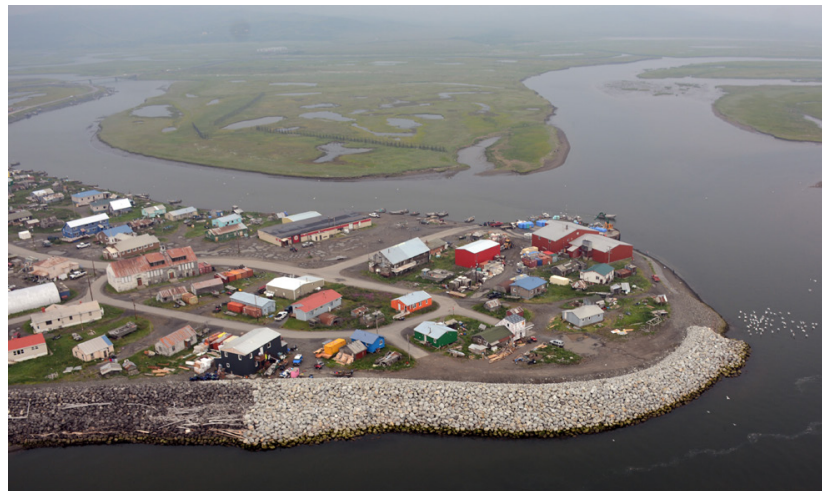

Figure 10. Oblique photograph of a portion of the rock revetment at Unalakleet, taken July 2015 (ShoreZone, 2019).

the long term. Rock revetments or rubble mounds were placed at Kivalina, Unalakleet, and St. Michael to mitigate erosion (figs. $7,10,11$ ). The community of Deering is located on a sand spit in Kotzebue Sound, and for the most part is fronted by an interlocking concrete revetment. In recent years, however, the revetment has been undermined by coastal storm activity (fig. 12). Without investments to maintain and repair infrastructure, such rock revetments, rubble mounds, and concrete revetments eventually become at risk to erosion again.

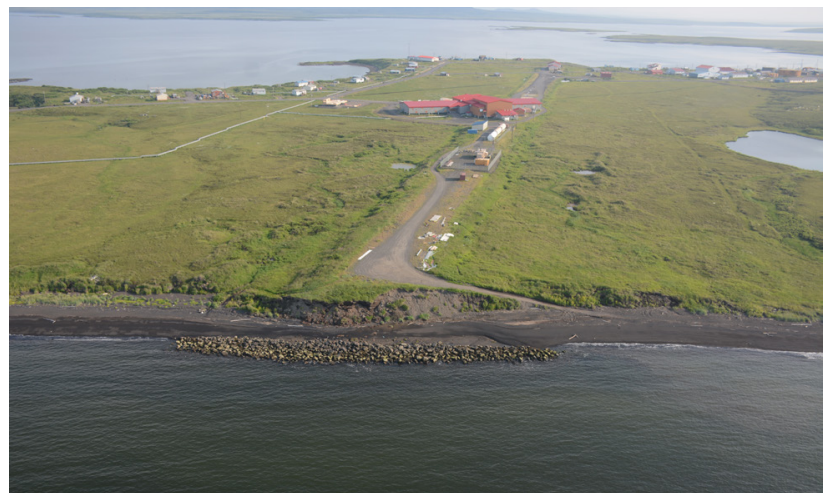

Figure 11. Oblique photograph of rock mound at St. Michael, taken July 2015 (ShoreZone, 2019).

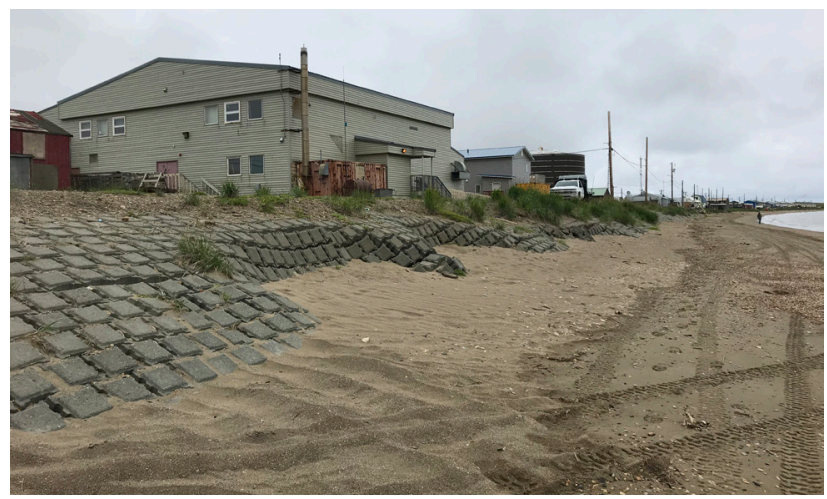

Figure 12. Erosion control structure at Deering, which was undermined and damaged by storm surges. Photo taken July 2018. 


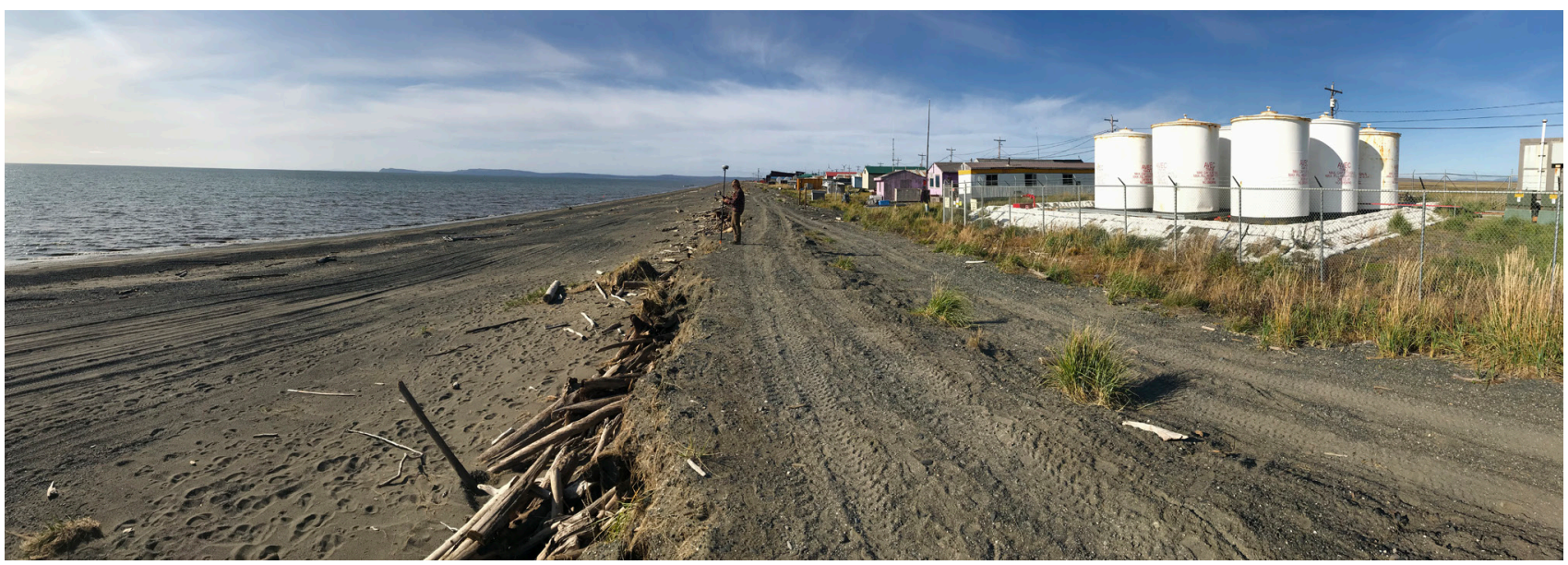

Figure 13. Unconsolidated gravel berm (used as a road) in front of the tank farm in Shaktoolik. Photo taken after a storm in August 2019 eroded the berm.

The community of Shaktoolik is located on a mixed sand-gravel spit at the head of Norton Sound. In 2015, the community began construction of an unconsolidated gravel berm because of its low cost compared to that of a rock revetment; however, gravel is more easily eroded. A storm in August 2019 impacted both Shaktoolik and nearby Unalakleet, causing no damage in Unalakleet but significantly eroding Shaktoolik's gravel berm (fig. 13).

\section{Yukon-Kuskokwim Delta}

The Yukon-Kuskokwim Delta of Alaska has huge expanses of low-elevation deltaic deposits that are discontinuously frozen with areas of high ice content (Jorgenson and Ely, 2001; Jorgenson

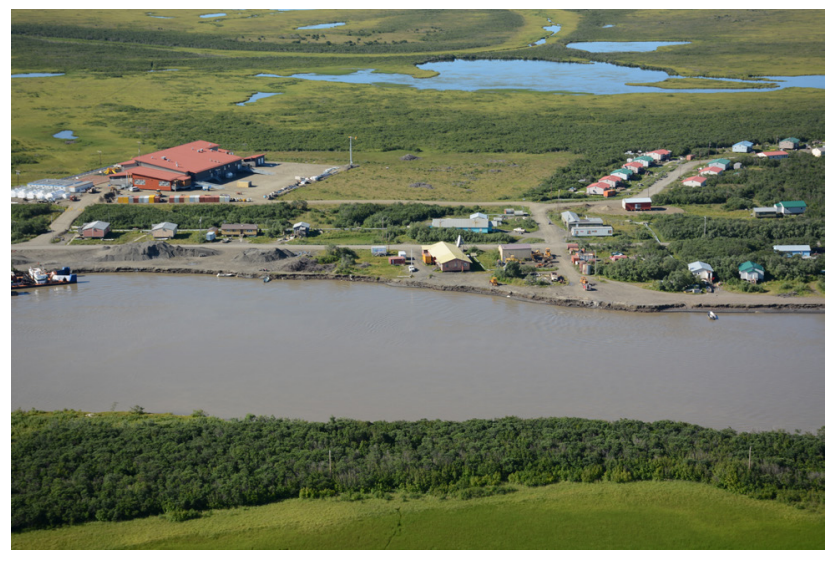

Figure 14. River bank at Alakanuk, where erosion has already undermined a road and other infrastructure. Photo taken August 2014 (ShoreZone, 2019). and others, 2008; Jorgenson and others, 2018; Whitley and others, 2018). Communities primarily have infrastructure located directly on the banks of rivers and eroding coastline, making any amount of erosion a threat to infrastructure (for example, at Alakanuk; fig. 14). The low elevation of the YukonKuskokwim Delta makes communities that are settled even very far inland (20-23 miles) susceptible to coastal flooding and erosion from storm surge (Terenzi and others, 2014), events that have the potential to further degrade permafrost through the salinization and thawing of flooded areas (for example, at Kwigillingok; fig. 15). The combination of low-elevation land and thaw-susceptible

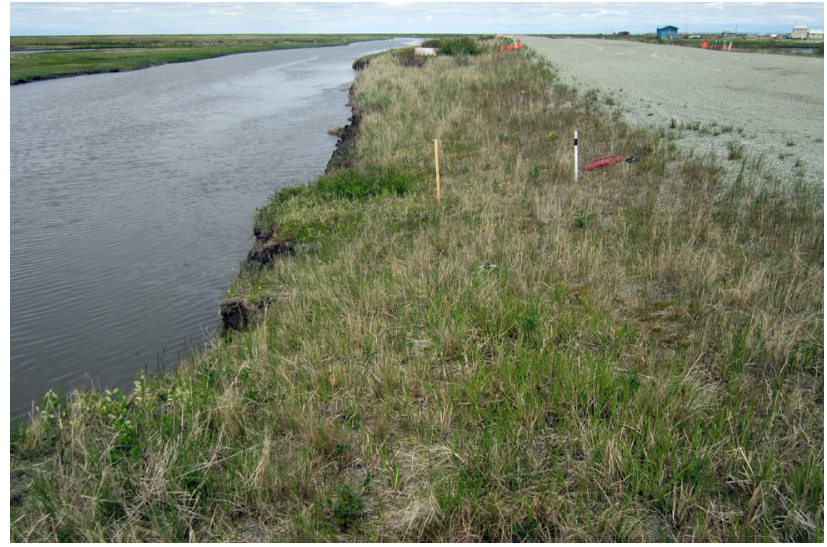

Figure 15. Erosion near the airstrip at Kwigillingok, which is also susceptible to permafrost degradation and flooding, which may lead to usteq. Photo taken June 2017. 
soils makes this region of Alaska particularly vulnerable to the combined impacts of flooding, erosion, and permafrost degradation. "Usteq" is the Yup'ik term for land collapse that involves the complex interactions of flooding, erosion, and permafrost degradation, which when combined can be disastrous (DHSEM, 2018). Usteq at the community of Kwigillingok has resulted in vast environmental changes across the landscape of the community. The combination of floods and thawing permafrost has resulted in lakes draining and rerouting across the community and near infrastructure, changing entire drainage systems. Due to the complex nature of these changes, the effects from usteq at Kwigillingok were not easily tracked through the shoreline change analysis conducted as part of this report.

Newtok, Alaska, had the highest measured rates of erosion in the state. Erosion at Newtok is two-fold: the community is located on a cutbank of the tidally influenced Ninglick River, where the channel has migrated very rapidly (fig. 16); and this portion of the Ninglick River is subject to waves that develop over the long fetch of the river's width, as well as storm surge from coastal storms. Erosion has the potential to impact community infrastructure including residences, steam houses, storage structures, the only water supply, and the high school and elementary school-all of which front the eroding river bank (Native Village of Newtok

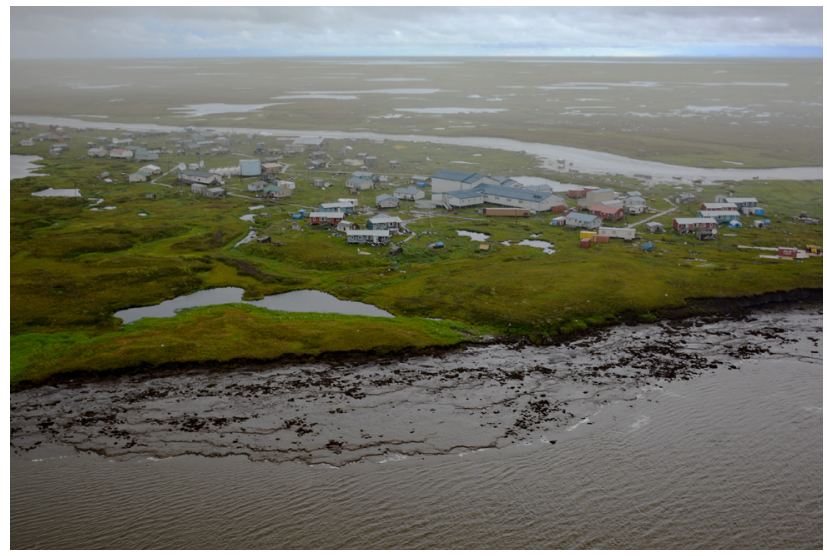

Figure 16. Oblique photograph of Newtok taken August 2014 (ShoreZone, 2019). Since then, erosion has begun to undermine the residential buildings nearest the river bank. and others, 2015). After 25 years of coordinated relocation efforts (from 1994 to 2019), Newtok relocated 30 percent of their population to a new community site (DCRA, 2019b); efforts are still underway to relocate the remaining 70 percent of the population.

The Yukon-Kuskokwim Delta has the highest population density of northern and western Alaska (Department of Labor and Workforce Development [DLWD], 2010). Many residences and critical facilities are at risk to imminent erosion; however, very few erosion control structures have been constructed to mitigate erosion to date. Limited construction could be due to lack of available rock in the region. The most successful strategy has been to move structures one building at a time through local efforts (e.g., Native Village of Kwigillingok and URS Corporation, 2015). Local capacity to move structures can be dependent on access to heavy equipment, as well as on funds for fuel and skilled labor. Consequently, most of these deltaic communities are now more at risk than the communities that remain higher up on statewide rankings (UAF and others, 2019), such as those that have had rock revetments built since their original assessment. For example, Nunam Iqua is relocating, abandoning, and demolishing coastal infrastructure in response to the encroaching shoreline $(6.9 \pm 1.3 \mathrm{ft}$ per year $[2.1 \pm 0.4 \mathrm{~m}$ per year]; fig. 17). These erosion impacts were noted but not

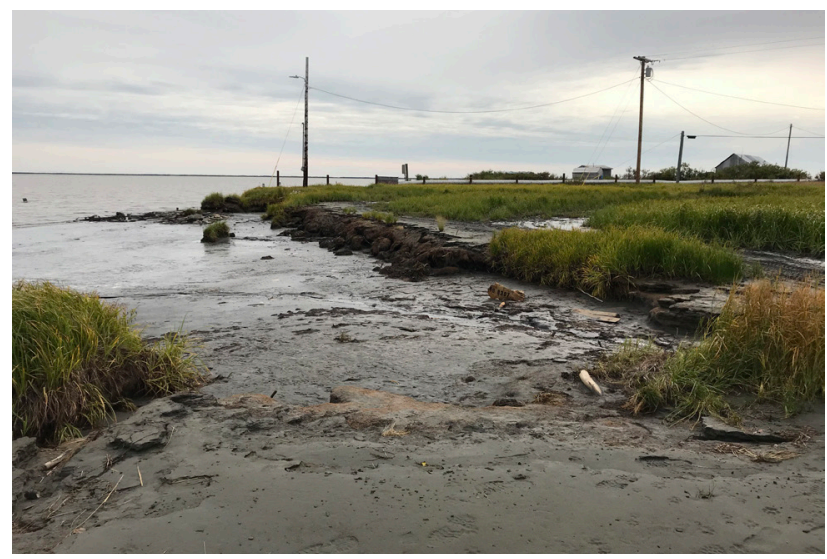

Figure 17. Erosion at Nunam lqua near power poles and community water source intake pipe. Photo taken August 2019. 
emphasized in hazard mitigation plans or economic development plans (Nunam Iqua Advisory Planning Board, 2017), and as a result, UAF and others (2019) ranked the community far lower than many places where almost no infrastructure is at imminent risk of erosion.

At communities where mitigation structures have been built, very limited investments have been made to maintain them. For example, in the 1980s, a concrete interlocking block revetment was installed at the community of Kotlik on the Yukon River. Though the structure reduced erosion rates, it is now in disrepair and beyond its original lifespan. The river banks are currently eroding, and some structures are now overhanging the river (fig. 18). Similarly, the community of Tununak is located on a mixed sand-gravel spit on Nelson Island, where erosion is mitigated by a gabion basket revetment along the entire spit, but sections are in need of repair after significant storm damage (fig. 19).

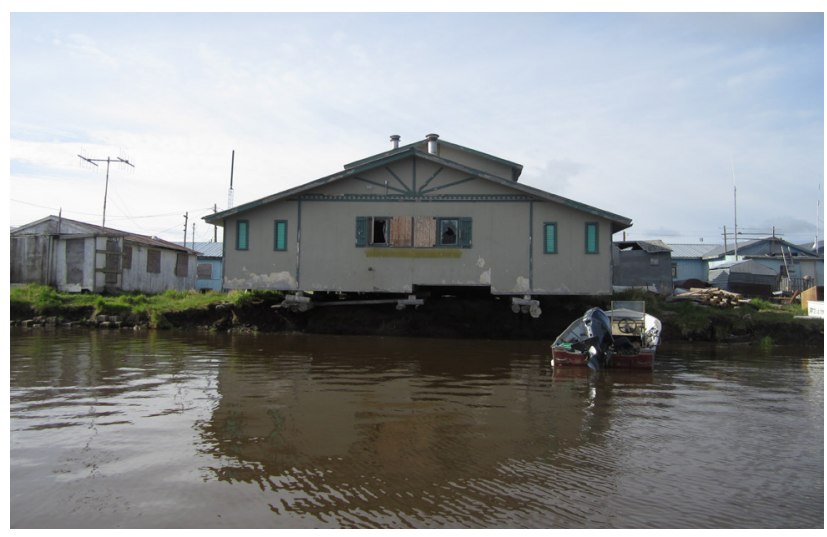

Figure 18. Building overhanging river bank at Kotlik. Photo taken June 2017. Concrete blocks from dilapidated NRCS erosion-control structure piled along river bank.

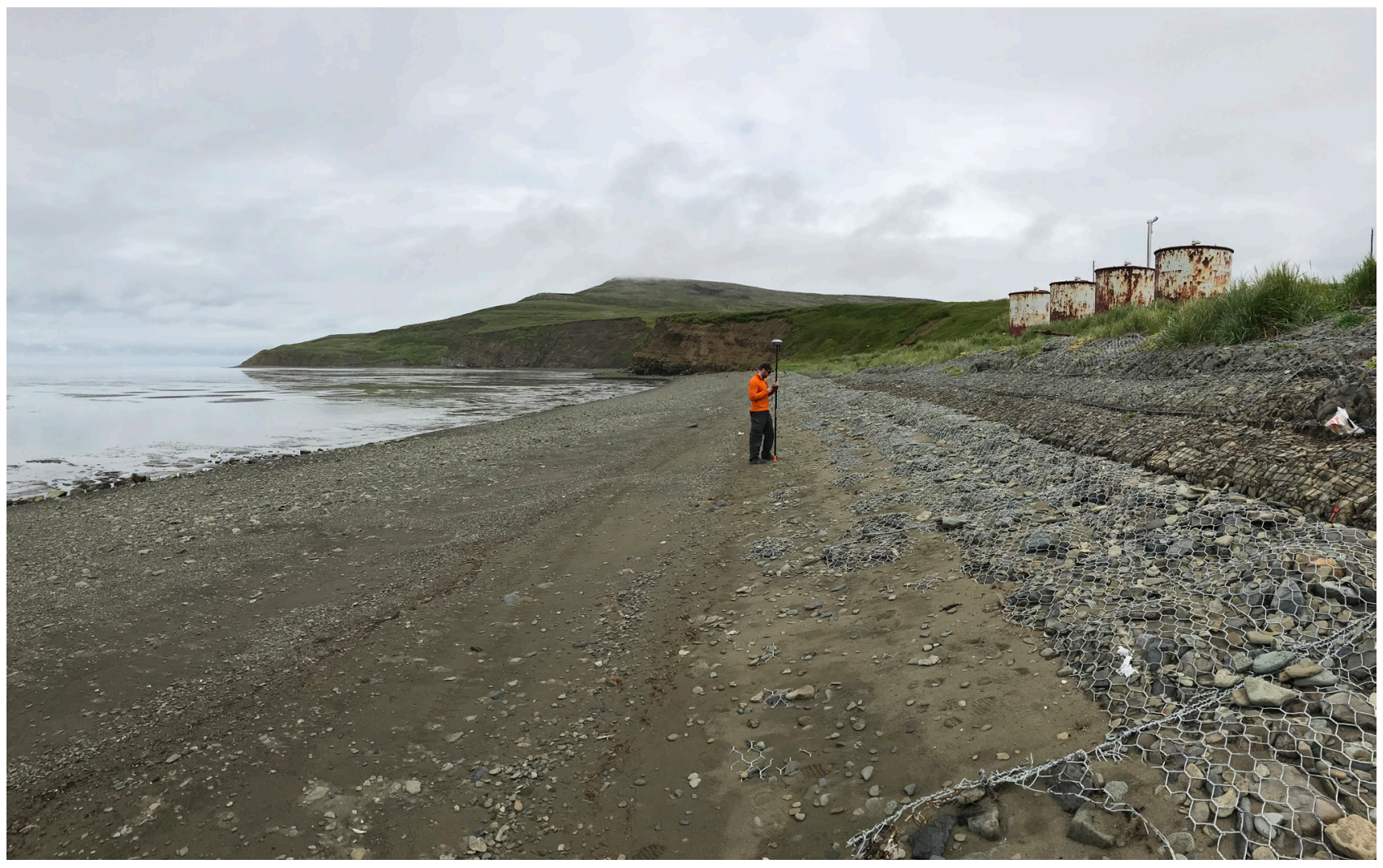

Figure 19. Gabion basket revetment at Tununak, August 2019. 


\section{Bristol Bay and Alaska Peninsula}

Most communities in Bristol Bay are perched on tall ( $>20$-ft-high) coastal bluffs as a result of the large tide range (macrotidal; fig. 20) and/or their proximity to river mouths. Bristol Bay communities are commonly centered around commercial salmon fishing sites and fish canneries that were first established in the early 1900s (Wright and others, 1985). Although Jorgenson and others (2008) show no permafrost in Bristol Bay, recent geotechnical surveys presented at the 2019 Alaska Forum on the Environment showed permafrost underlying a wastewater treatment facility in Naknek. Additional research is needed to understand where permafrost is around Bristol Bay and how permafrost might influence erosion. The tall and exposed nature of the bluffs makes them vulnerable to groundwater seepage, overland runoff, and slumping. Coastal bluffs are fronted by mixed sand-gravel beaches, but the bluffs themselves are primarily composed of consolidated and/or clay-rich materials that are more resistant to wave impacts, compared to sandy beaches. During coastal storms, materials that slumped or were transported to the beach from the bluffs are eroded by waves (fig. 21). Waves can also cut niches at the base of the bluffs, which destabilizes the material above, resulting in new slumps.

Communities located at river mouths in Bristol Bay are subject to erosion from coastal and riverine processes. In Dillingham, for example, the community wastewater lagoon, located at the confluence of the Wood and Nushagak rivers, is at risk to erosion. Recent community-based monitoring of erosion has shown coastal storms inundate and kill vegetation fronting the lagoon; without this vegetation, regular changes in water levels and waves have eroded the bank as much as $9 \mathrm{ft}(2.7 \mathrm{~m})$ after a single storm event.

On the Alaska Peninsula in Bristol Bay, the coastline is predominantly covered by volcanic materials from activity of the Aleutian Arc. The community of Port Heiden is located on pumice-rich coastal bluffs. The unconsolidated material is highly erodible, even single storm events can result in up to 38

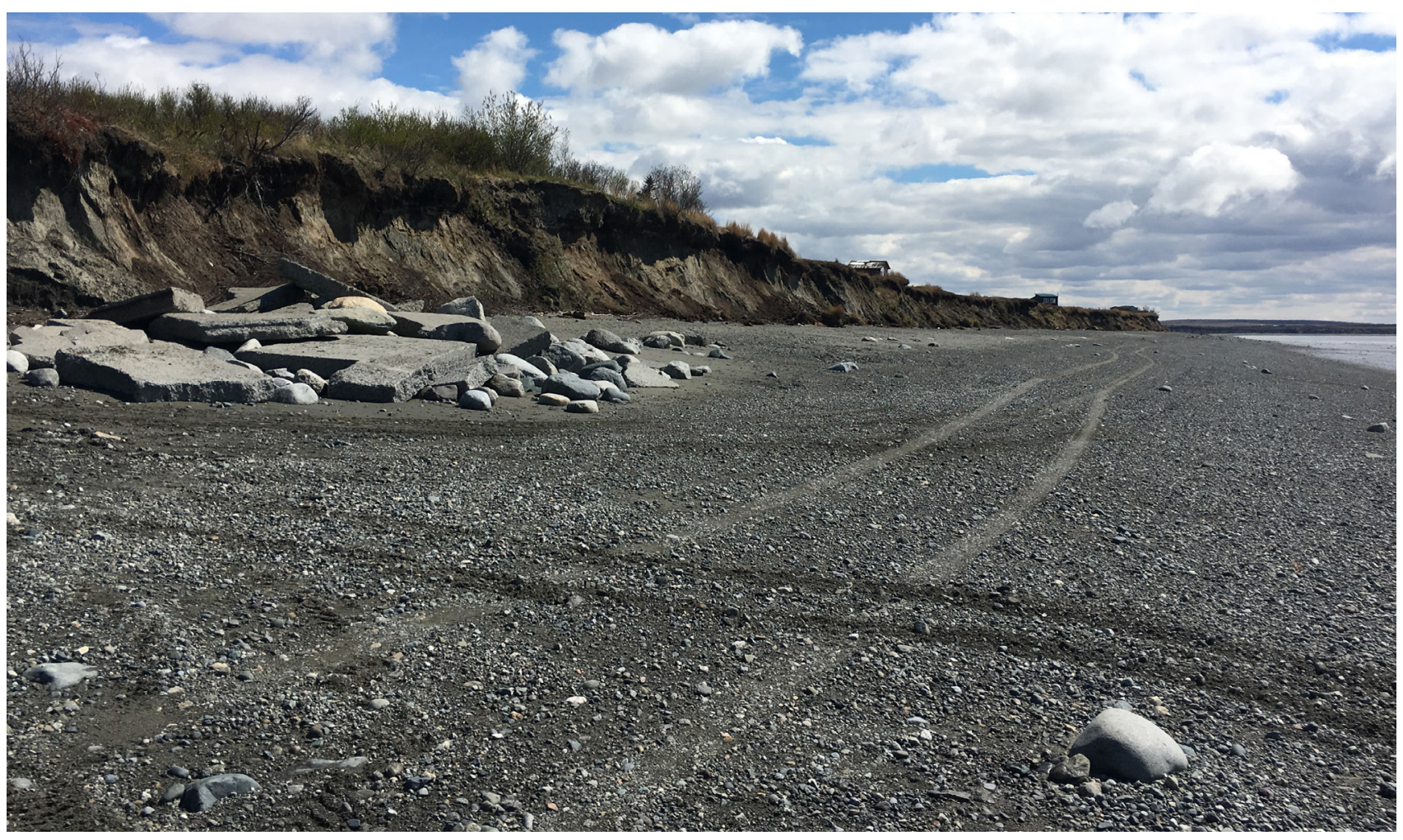

Figure 20. Erosion of coastal bluffs at Naknek. Photo taken May 2017. 
$\mathrm{ft}(11.6 \mathrm{~m})$ of erosion (Buzard and others, 2018; Kinsman and Gould, 2014). Although the community relocated most infrastructure in the 1980's, some buildings, pipes, and foundations eroded onto the beach and into Bristol Bay (Alaska Native Tribal Health Consortium [ANTHC], 2018). In 2019, Goldfish Lake, a large lake used for subsistence activities, was breached and partially drained (fig. 22). This resulted in the loss of a main road that provided access to the old village of Meshik, a safe boat launching site, and subsistence resources.

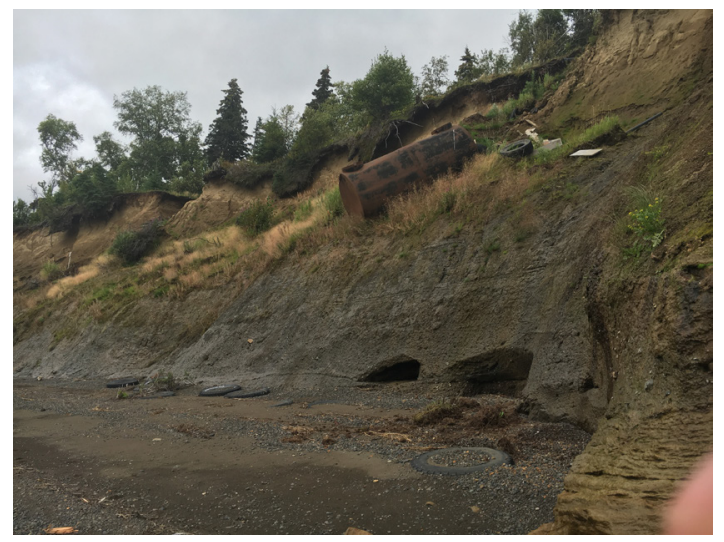

Figure 21. Coastal bluffs at Dillingham. Photos taken August 2016.

\section{Regional Summary}

These cases demonstrate how the age and unreliability of erosion control structures used in Alaska could result in higher erosion rates in the future, compared to the long-term rates presented in this report. Although erosion rates at communities with rock or concrete revetments are lower compared to other communities, community infrastructure is currently so close to the shoreline that even minor amounts of erosion-or failure of erosion control structures - could result in disaster. Thus, a slow erosion rate does not necessarily indicate low erosion vulnerability.

Although many communities in northern and western Alaska are taking mitigation actions to reduce the threat of erosion, it is yet to be seen how climate change may impact the drivers of shoreline change. Due to the lack of oceanographic and terrestrial instrumentation to monitor environmental changes at communities, all regions of Alaska still require a great deal of study in order to better understand the relevant coastal processes and to project future changes of shoreline positions.

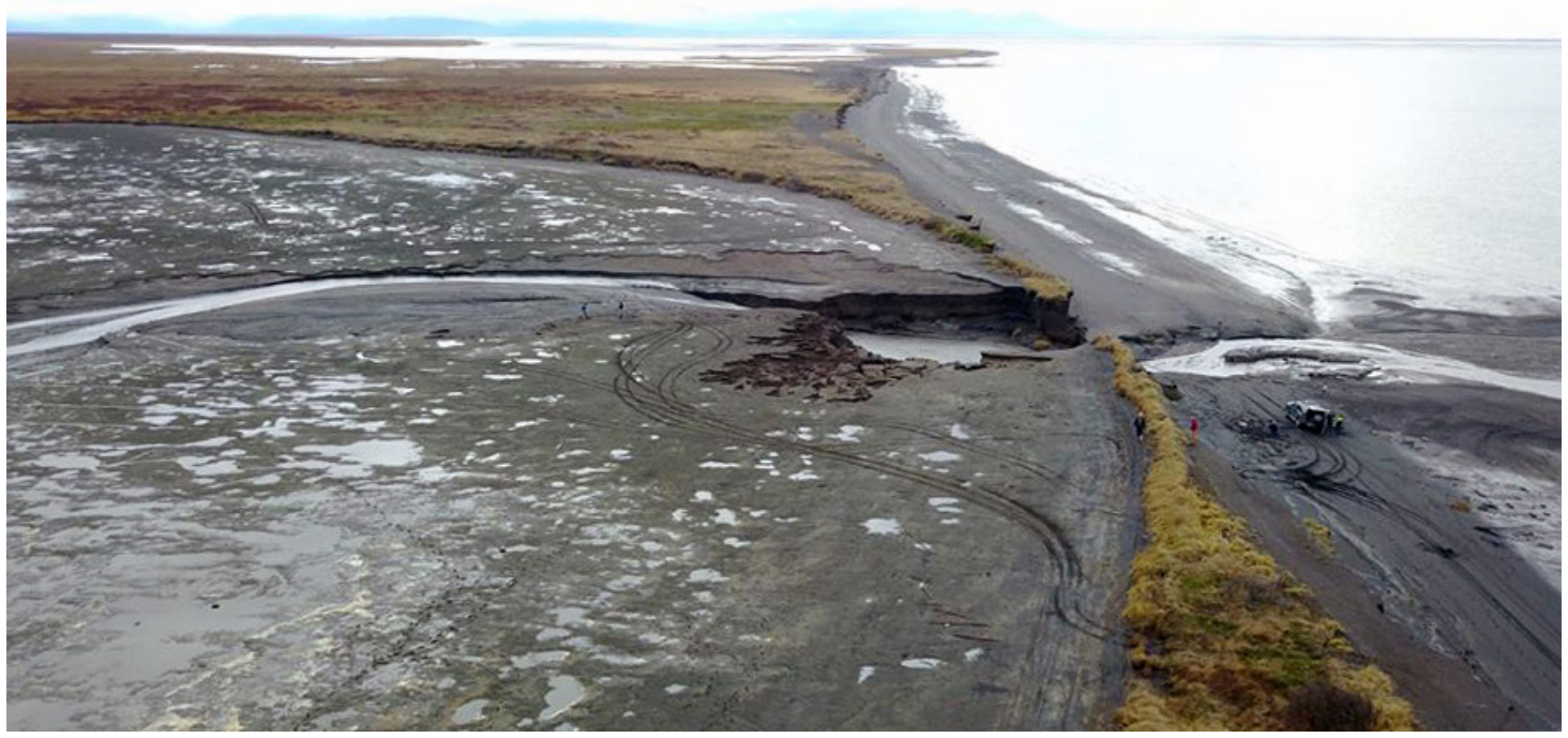

Figure 22. Erosion and subsequent drainage of Goldfish Lake at Port Heiden. Photo taken November 2019 by the Native Village of Port Heiden. 


\section{Climate Change}

Erosion rates determined by this study were derived from historical data from the 1950s to 2019. Today, Alaska is undergoing unprecedented environmental changes that may accelerate erosion rates moving forward, including but not limited to the following:

- Relative sea level change (e.g., Sweet and others, 2017),

- Sea ice decline leading to increased fetch and an opening up of coastal waters to wind and wave activity (e.g., Farquharson and others, 2018; Overeem and others, 2011; Steele and Dickinson, 2016),

- Changing patterns in coastal storms (e.g., Fang and others, 2018; Vermaire and others, 2013),

- Changing ocean currents (e.g., Armitage and others, 2020),

- Increased air and ocean temperatures thawing coastal permafrost (e.g., Jones and others, 2018; Smith and others, 2010), and

- Increased precipitation and groundwater runoff eroding coastal bluffs and thawing permafrost (Intergovernmental Panel on Climate Change [IPCC], 2014; Thoman and Walsh, 2019).

Although there are many recognized environmental changes (listed above), their impacts on shoreline change near communities and coastal infrastructure are not well established. The Arctic is warming faster than the global average (IPCC, 2014). Sea ice has declined steadily (Perovich and others, 2017), which increases open water days and ocean wave activity, which in turn can impact shorelines at a higher frequency (Fang and others, 2018; Vermaire and others, 2013). Increases in air and water temperature (Overland and others, 2017; Steele and Dickinson, 2016) are expected to degrade Arctic permafrost (Jones and others, 2018;
Smith and others, 2010). Changes in the amount, timing, and occurring temperature of precipitation will mean not only changes in discharge at riverine communities (IPCC, 2014), but also changes to erosion from the terrestrial environment at bluffs and along coastal rivers. Relative sea level change will also play a role in shoreline change in Alaska. For northern and western Alaska, current rates of relative sea level change are stable (Sweet and others, 2017). However, when sea level is modeled for future global scenarios, relative sea level could increase from 1 to $10 \mathrm{ft}$ ( 0.3 to $3 \mathrm{~m})$ across northern and western Alaska by 2100 (from intermediate to extreme scenarios; Sweet and others, 2017). The wide range of uncertainty in modeled projections is the result of a lack of accurate water level monitoring stations and continually operating reference stations in the region (Overbeck, 2018).

The way the coast responds to changing environmental conditions will also depend on the existing shoreline morphology and underlying framework geology, which differ vastly across the state. Future scenarios for planning should consider the possible changes in erosion rates due to a changing climate, but the amount of uncertainty associated with climate models should also be reflected so as not to alarm communities subject to coastal erosion where uncertainty in climate scenarios is high.

\section{Community-Centered Hazard Mapping}

Kettle and others (2019) recently found that the products of most Western science and hazard research do not meet the needs of small-community planners in Alaska (participants of surveys were from mostly tribal councils, villages, and communities, with a 26 percent response rate). Science products lack the detail necessary for community-level planning, and are often presented in a format that is difficult to understand (Kettle and others, 2019). For example, Macander and others (2014) 
utilized low-resolution satellite imagery to measure shoreline change in western Alaska; however, the resultant product provided one value of erosion or accretion for any given community. Luijendijk and others (2018) utilized higher resolution satellite imagery to conduct an analysis similar to Macander and others (2014); however, their analysis did not extend to all coastal communities, abruptly stopping (likely where data were no longer available) in the northern Arctic, and excluded communities of inland coastal rivers. Although the data used for the analysis were higher in resolution, Luijendijk and others (2018) did not compute shoreline change rates at enough transects along the coastline for the final map tool to provide enough information for community-level planning.

The maps associated with this report do fulfill the needs for coastal planning and engineering feasibility assessments in Alaska communities, based on the quality of the baseline data used for the assessment (high-resolution- 1 to $3 \mathrm{ft}$ [0.3 to $1 \mathrm{~m}$ ] ground sample distance and spatially accurate-shoreline change rate uncertainty below 44 percent of the maximum rate of erosion for shorelines eroding greater than $1 \mathrm{ft}$ per year $[0.3 \mathrm{~m}$ per year]), the frequency at which shorelines were measured along the coast (every $82 \mathrm{ft}[25 \mathrm{~m}]$ ), and the output format. The maps were developed as "small map templates" using 8.5 x 11-inch format and are meant to be printed with small printers, which are typically the only printing source for community tribal and city offices. Each map sheet is specific to the community footprint and shows enough detail to determine, from one building to the next, how at risk that portion of the shoreline is. Maps also include one map layer of data to simplify what the user sees. Although the map sheets are an improvement over what is currently available, there are still many ways in which they could be enhanced for planning by Alaska communities; DGGS will pursue such enhancements in future versions of shoreline change maps.
Many of Alaska’s coastal communities have very small populations (dozens to a few thousand people) and lack the technical expertise and staffing capacity to respond to erosion near infrastructure (e.g., to apply for and track progress of grant applications to multiple state and federal agencies to mitigate erosion; [GAO, 2003; GAO, 2009]). With that in mind, agencies that have a fiscal obligation to assist communities vulnerable to erosion can utilize the shoreline change rates created in this report to update analyses that can lead to community prioritizations (e.g., GAO, 2003; GAO, 2009; UAF and others, 2019). The individual community maps show the level of detail necessary to determine which structures are vulnerable to erosion and may need to be moved to avoid damage, thus making the maps a critical tool for the planning and implementation phases of hazard mitigation. The community should play a key role in developing the evaluation criteria. An example of this process was provided in the Shishmaref Relocation Site Feasibility Study (AECOM Technical Services, 2016), where protection-in-place and relocation alternatives were evaluated against criteria for the physical environment, construction and utilities factors, social and access factors, and cost implications.

Many of Alaska's coastal communities are primarily home to Indigenous people, who rely on Indigenous knowledge to interact with and make decisions about their changing environment:

"Indigenous knowledge is a systematic way of thinking applied to phenomena across biological, physical, cultural and spiritual systems. It includes insights based on evidence acquired through direct and long-term experiences and extensive and multigenerational observations, lessons and skills. It has developed over millennia and is still developing in a living process, including knowledge acquired today and in the future, and it is passed on from generation to generation." (Inuit Circumpolar Council, 2013) 
Alaska's Indigenous knowledge holders have a deep understanding of the changes occurring in the environment; however, many challenges remain in using multiple knowledge frameworks to respond to and mitigate coastal hazards. The framework for the co-production of knowledge is predicated on equity between Indigenous and non-Indigenous knowledge holders in defining a problem, identifying questions, developing methods, gathering information, analyzing information, communicating, reviewing results, accessing and controlling information, and reciprocity (Behe and others, 2020).

This report does not solve all of the problems, including the integration of Indigenous knowledge (through co-production) or the comparison of shorelines to the location of infrastructure in order to determine vulnerability (the next phase of this work); nor does it take into account how climate change may influence future shoreline change rates. However, these maps do provide a transparent, consistent, and quantitative assessment of shoreline change at a scale necessary for community planning, which has not been available to date. Progress in developing baseline datasets and mapping shorelines has made it possible to create such maps for 44 communities in northern and western Alaska.

\section{CONCLUSIONS}

This report is the first consistent and quantitative assessment of erosion for Alaska communities to date. State and federal agency coordination was critical to develop the quality baseline data necessary to conduct community shoreline change assessments. This assessment found that 57 percent of coastal communities in northern and western Alaska have experienced erosion greater than $3.3 \mathrm{ft}$ per year ( $1 \mathrm{~m}$ per year) over the last 60 years. Throughout the different regions of Alaska, communities have responded to erosion in different ways, whether through building rock or concrete revetments, using gravel berms, or moving individual structures away from eroding banks. Although many communities are threatened by erosion, each community has a different level of vulnerability that could not be determined through this work alone. Community-centered maps were created to display the geographic extent of erosion rates for the purpose of community planning; however, we were unable to use the co-production of knowledge to create them. In the future, erosion rates in Alaska are expected to be impacted by coastal management practices of maintaining or building new coastal structures as well as by changes to the environment resulting from climate change.

\section{ACKNOWLEDGMENTS}

This work was funded by FEMA, the State of Alaska, the Denali Commission, and the U.S. Bureau of Indian Affairs. The UAF Arctic Coastal Geoscience Lab provided great assistance in delineating shorelines in Bristol Bay. Baseline data was critical to this work, which would not have been collected without the work of Nicole Kinsman during her time as the Coastal Hazards Program manager and that of Ann Gibbs with the U.S. Geological Survey. Funding for the DGGS Coastal Hazards Program has come from various sources, and many collaborators have assisted with field investigations. This report would not have been possible without the thoughtful and thorough peer reviews by Ann Gibbs, Chris Maio, and Sally Russell Cox. 


\section{REFERENCES}

AECOM Technical Services, 2016, Shishmaref relocation site selection feasibility study: City of Shishmaref, 308 p. https://www.commerce. alaska.gov/web/Portals/4/pub/Shishmaref_Site_ Selection_Feasibility_Study_FINAL_022316.pdf

Alaska Department of Labor \& Workforce Development (DLWD), 2010, Research and Analysis, 2010 Census: Department of Labor and Workforce Development. http://live.laborstats. alaska.gov/cen/maps.cfm\#cen2010

Alaska Department of Transportation \& Public Facilities (DOT\&PF), 2019, Point Hope runway realignment: Department of Transportation \& Public Facilities. http://dot.alaska.gov/nreg/phoairport/

Alaska Division of Community \& Regional Affairs (DCRA), 2020, Community resilience programs: community decision making continuum, https:// www.commerce.alaska.gov/web/Portals/4/ pub/Community\%20Resilience $\% 20 \& \% 20$ Climate\%20Adaptation/DCRA_Community_ Decision-Making_Continuum.pdf

2019a, Community profile maps: Department of Commerce, Community, and Economic Development. https://www.commerce.alaska. gov/web/dcra/PlanningLandManagement/CommunityProfileMaps.aspx

_ 2019b, Newtok Planning Group: Department of Commerce, Community, and Economic Development. https://www.commerce. alaska.gov/web/dcra/planninglandmanagement/ newtokplanninggroup.aspx

Alaska Division of Homeland Security \& Emergency Management (DHSEM), 2018, Alaska State Hazard Mitigation Plan: Chapter 6 Natural Hazards: Division of Homeland Security \& Emergency Management, 152 p. https:// ready.alaska.gov/Plans/Mitigation/Documents/ Mitigation\%20Plan\%20Chapters/Ch06NaturalHazards.pdf

Alaska Native Tribal Health Consortium (ANTHC), 2018, Climate change in Port Heiden, Alaska: strategies for community health: Alaska Native Tribal Health Consortium, 60 p. https://anthc.org/wpcontent/uploads/2018/10/ANTHC-Port-Heiden_ Final.pdf
American Society for Photogrammetry and Remote Sensing (ASPRS), 2014, Positional accuracy standards for digital geospatial data: American Society for Photogrammetry and Remote Sensing, 39 p. http://www.asprs.org/a/society/divisions/ pad/Accuracy/ASPRS_Positional_Accuracy_ Standards_for_Digital_Geospatial_Data_Draft_ Rev5_V1.pdf

Armitage, T.W.K., Manucharyan, G.E., Petty, A.A., Kwok, Ron, and Thompson, A.F., 2020, Enhanced eddy activity in the Beaufort Gyre in response to sea ice loss: Nat. Commun., v. 11, no. 761. https://doi.org/10.1038/s41467-02014449-z

Barnhart, K.R., Anderson R.S., Overeem, Irina, Wobus, Cameron, Clow, G.D., Urban, F.E., 2014, Modeling erosion of ice-rich permafrost bluffs along the Alaskan Beaufort Sea coast: Journal of Geophysical Research, Earth Surface, v. 119, no. 5, p. 1,155-1,179 https://doi.org/10.1002/ 2013JF002845

Barnhart, K.R., Overeem, Irina, and Anderson R.S., 2014, The effect of changing sea ice on the physical vulnerability of Arctic coasts: The Cryosphere, v. 8, p. 1,777-1,799. https://doi.org/10.5194/tc-8$1777-2014$

Behe, Carolina, Daniel, Raychelle, and RaymondYakoubian, Julie, 2020, Co-production of knowledge: Kawerak, Inc. https://kawerak. org/co-production-of-knowledge-in-researchvaluing-traditional-knowledge/

Boak, E.H., and Turner, I.L., 2005, Shoreline definition and detection: a review: Journal of Coastal Research, p. 688-703.

Buzard, Richard, Maio, Chri, Overbeck, Jacquelyn, Lujan, Erica, Flensburg, Sue, Holen, David, Dunham, Gabriel, 2018, Laying the foundation for resilient coastal communities: case studies-Port Heiden and Goodnews Bay, Alaska: Alaska Sea Grant, 14 p. https://adaptalaska. org/wp-content/uploads/2018/11/ResilientCoastal-Communities-bulletin_lowres.pdf

Fang, Zhanpei, Freeman, P.T., Field, C.B., and Mach, K.J., 2018, Reduced sea ice protection period increases storm exposure in Kivalina, Alaska: Arctic Science, v. 4, p. 525-537. 
Farquharson, L.M., Mann, D.H., Swanson, D.K., Jones, B.M., Buzard, R.M., and Jordan J.W., 2018, Temporal and spatial variability in coastline response to declining sea-ice in northwest Alaska: Marine Geology, v. 404, p. 71-83. https://doi. org/10.1016/j.margeo.2018.07.007

Fletcher, C.H., Romine, B.M., Genz, A.S., Barbee, M.M., Dyer, Matthew, Anderson, T.R., Lim, S.C., Vitousek, Sean, Bochicchio, Christopher, and Richmond, B.M., 2012, National assessment of shoreline change: Historical shoreline change in the Hawaiian Islands: U.S. Geological Survey Open-File Report 2011-1051.

Gibbs, A.E., Nolan, Matt, Richmond, B.M., Snyder, A.G., and Erikson, L.H., 2019, Assessing patterns of annual change to permafrost bluffs along the North Slope coast of Alaska using high-resolution imagery and elevation models: Geomorphology, v. 336, p. 152-164. https://doi.org/10.1016/j. geomorph.2019.03.029

Gibbs, A.E., Ohman, K.A., Coppersmith, R., and Richmond, B.M., 2017, National Assessment of Shoreline Change: A GIS compilation of updated vector shorelines and associated shoreline change data for the north coast of Alaska, U.S. Canadian border to Icy Cape: U.S. Geological Survey data release. https://doi.org/10.5066/F72Z13N1

Gibbs, A.E., and Richmond, B.M., 2015, National assessment of shoreline change-historical shoreline change along the north coast of Alaska, U.S.-Canadian border to Icy Cape: U.S. Geological Survey Open-File Report 2015-1048, 96 p. https://dx.doi.org/10.3133/ofr20151048

Gibbs, A.E., Snyder, A.G., and Richmond, B.M., 2019, National assessment of shoreline change: historical shoreline change along the north coast of Alaska, Icy Cape to Cape Prince of Wales: U.S. Geological Survey Open-File Report 2019-1146. https:/doi.org/10.3133/ofr20191146

Gorokhovich, Yuri, and Leiserowiz, Anthony, 2012, Historical and future coastal changes in northwest Alaska: Journal of Coastal Research, v. 28, no. 1A, p. 174-186. https://doi.org/10.2112/ JCOASTRES-D-11-00031.1

Gould, A.I., Kinsman, N.E.M., and Hendricks, M.D., 2015, Guide to projected shoreline positions in the Alaska shoreline change tool, in DGGS Staff, Alaska shoreline change tool: Alaska Division of Geological \& Geophysical Surveys Miscellaneous Publication 158, 11 p. http://doi. org/10.14509/29503

Griggs, Gary, 2005, The impacts of coastal armoring: Shore and Beach, v. 73, no. 1, p. 13-22.

Hapke, C.J., Himmelstoss, E.A., Kratzmann, M.G., List, J.H., and Thieler, E.R., 2010, National Assessment of Shoreline Change: Historical Shoreline Change along the New England and Mid-Atlantic Coasts: U.S. Geological Survey Open-File Report 2010-1118.

Hapke, C.J. and Reid, David, 2007, National assessment of shoreline change: Part 4, historical coastal cliff retreat along the California coast: U.S. Geological Survey Open-File Report 2007-1133. Hapke, C.J., Reid, David, Richmond, B/M., Ruggiero, Peter, List, Jeff, 2006, National assessment of shoreline change: Part 3, historical shoreline change and associated coastal land loss along the sandy shorelines of the California coast: U.S. Geological Survey Open-File Report 2006-1219. Harper, John, April 16, 2014, The ShoreZone coastal vulnerability indices: National Oceanic \& Atmospheric Administration. https://www. fisheries.noaa.gov/resource/document/shorezonecoastal-vulnerability-indices

Himmelstoss, E.A., Farris, A.S., Henderson, R.E., Kratzmann, M.G., Ergul, Ayhan, Zhang, Ouya, Zichichi, J.L., and Thieler, E.R., 2018, Digital Shoreline Analysis System: U.S. Geological Survey, v. 5. https://code.usgs.gov/cch/dsas

Immediate Action Working Group (IAWG), 2008, Recommendations report to the Governor's subcabinet on climate change: Immediate Action Working Group, 168 p. https://dec.alaska.gov/ climate-change/

Intergovernmental Panel on Climate Change (IPCC), 2014, Climate change 2014: synthesis report. Contribution of working groups I, II and III to the fifth assessment report of the Intergovernmental Panel on Climate Change in Core Writing Team, Pachauri, R.K., and Meyer, L.A., eds., Intergovernmental Panel on Climate Change, Geneva, Switzerland, 151 p. https:/www.ipcc.ch/site/assets/up- 
loads/2018/02/SYR_AR5_FINAL_full.pdf

Inuit Circumpolar Council (ICC), 2013, Application of traditional knowledge in the Arctic Council: Inuit Circumpolar Council, 2 p. https://iccalaska. org/wp-icc/wp-content/uploads/2016/03/ Application-of-IK-in-the-Arctic-Council.pdf

Jones, B.M., Arp, C.D., Jorgenson, M.T., Hinkel, K.M., Schmutz, J.A., and Flint, P.L., 2009, Increase in the rate and uniformity of coastline erosion in Arctic Alaska: Geophysical Research Letters, v. 36, no. 3. https://doi.org/10.1029/2008GL036205

Jones, B.M., Farquharson, L.M., Baughman, C.A., Buzard, R.M., Arp, C.D., Grosse, Guido, Bull, D.L., Gunther, Frank, Nitze, Ingmar, Urban, Frank, 2018, A decade of remotely sensed observations highlight complex processes linked to coastal permafrost bluff erosion in the Arctic: Environmental Research Letters, v. 13, p. 115001. Jones, B.M., Hinkel, K.M., Arp, C.D., and Eisner, W.R., 2008, Modern erosion rates and loss of coastal features and sites, Beaufort Sea coastline, Alaska: Arctic, v. 61, no. 4, p. 361-372.

Jones, B.M., Stoker, J.M., Gibbs, A.E., Grosse, Guido, Romanovsky, V.R., Douglas, T.A., Kinsman, Nicole E.M., Richmond, B.M., 2013, Quantifying landscape change in an arctic coastal lowland using repeat airborne lidar: Environmental Research Letters, v. 8, no. 4.

Jorgenson, M.T., Frost, G.V., Dissing, Dorte, 2018, Drivers of landscape changes in coastal ecosystems on the Yukon-Kuskokwim Delta, Alaska: Remote Sensing, v. 10, 1,280 p. https://doi.org/10.3390/ rs 10081280

Jorgenson, Torre, and Ely, C.R., 2001, Topography and flooding of coastal ecosystems on the YukonKuskokwim Delta, Alaska: Implications for sealevel rise: Journal of Coastal Research, p. 124-136. Jorgenson, Torre, Yoshikawa, Kenji, Kanevskiy, Mikhail, Shur, Yuri, Romanovsky, Vladimir, Marchenko, Sergei, Grosse, Guido, Brown, Jerry, and Jones, Ben, 2008, Permafrost characteristics of Alaska (poster): Ninth International Conference on Permafrost, Fairbanks, Alaska. http://permafrost.gi.alaska.edu/sites/default/ files/AlaskaPermafrostMap_Front_Dec2008_ Jorgenson_etal_2008.pdf

Kenai Peninsula Borough, 2017, Risk report FEMA region X-Kenai Peninsula Borough, Alaska: Federal Emergency Management Agency, 95 p. https://www.commerce.alaska.gov/web/Portals/4/ pub/Risk_Report_Kenai_Final.pdf

Kettle, N., Chase, M., O'domin, O., Roehl, D., and Cozzetto, K., 2019, Building capacity for tribal climate adaptation and planning in Alaska: a post-training needs assessment: International Arctic Research Center, University of Alaska Fairbanks, 7 p. https://uaf-accap.org/wp-content/ uploads/2019/11/CAP-training-eval-ANTHCITEP-Full-Approved-.pdf

Kinsman, N.E.M., and Gould, A.I., 2014, Contemporary shoreline retreat rates at Meshik in Port Heiden, Alaska: Alaska Division of Geological \& Geophysical Surveys Preliminary Interpretive Report 2014-4, 21 p. http://doi. org/10.14509/27321

Kratzmann, Meredith, Himmelstoss, E.A., Ruggiero, Peter, Thieler, E.R., and Reid, David, 2013, National Assessment of Shoreline Change: A GIS Compilation of Vector Shorelines and Associated Shoreline Change Data for the Pacific Northwest Coast: U.S. Geological Survey Open-File Report 2012-1008.

Luijendijk, Arjen, Hagenaars, Gerben, Ranasinghe, Roshanka, Baart, Fedor, Donchyts, Gennadii, and Aarninkhof, Stefan, 2018, The State of the World's Beaches: Scientific Reports, v. 8. https:// doi.org/10.1038/s41598-018-24630-6

Macander, M.J., Swingley, C.S., and Spencer, S.R., 2014, Extensive mapping of Bering Sea and Gulf of Alaska coastal change by Landsat time-series analysis, 1972-2013; Phase II: Full study area: Western Alaska Landscape Conservation Cooperative Project 2013-24, ABR, Inc., Final Project Report, 81 p. https:// westernalaskalcc.org/projects/Lists/Project $\% 20$ Products/Attachments/69/Extensive_Mapping of_Coastal_ChangeWALCC_1972-2013_Final_ Report_web.pdf

Mangor, Karsten, Dronen, N.K., Kaergaard, K.H., and Kristensen, S.E., February 2017, Shoreline management guidelines: DHI, 4th edition, $462 \mathrm{p}$. https://www.dhigroup.com/upload/campaigns/ ShorelineManagementGuidelines_Feb2017.pdf 
Mars, J.C., and Houseknecht, D.W., 2007, Quantitative remote sensing study indicates doubling of coastal erosion rate in past $50 \mathrm{yr}$ along a segment of the Arctic coast of Alaska: Geology, v. 35, no. 7, p. 583-586. https://doi.org/10.1130/ G23672A.1

Moore, L.J., Ruggiero, Peter, List, J.H., 2006, Comparing mean high water and high water line shorelines: should proxy-datum offsets be incorporated into shoreline change analysis?: Journal of Coastal Research, v. 22, no. 4, p. 894-905.

Morton, R.A., and Miller, T.L., 2005, National assessment of shoreline change: Part 2, Historical shoreline changes and associated coastal land loss along the U.S. southeast Atlantic coast, U.S. Geological Survey Open-File Report 2005-1401. Morton, R.A., Miller, T.L., Moore, L.J., 2004, National assessment of shoreline change: Part 1, historical shoreline changes and associated coastal land loss along the U.S. Gulf of Mexico: U.S. Geological Survey Open-File Report 2004-1043.

National Oceanic \& Atmospheric Administration (NOAA), 2020, Tidal Datums. https://tidesand currents.noaa.gov/datum_options.html

Native Village of Kwigillingok and URS Corporation, 2015, Village of Kwigillingok hazard mitigation plan: Federal Emergency Management Agency, 174 p. https:/www.commerce.alaska. gov/dcra/DCRARepoExt/RepoPubs/Plans/ Kwigillingok\%202015\%20THMP.pdf.pdf

Native Village of Newtok, AECOM+URS Corporation, and BP\&D, 2015, Newtok Village tribal hazard mitigation plan update: Federal Emergency Management Agency, 82 p. https://www.commerce.alaska.gov/web/Portals/4/pub/2015_Newtok_HMP.pdf

Nunam Iqua Advisory Planning Board, 2017, Nunam Iqua Hazard Mitigation Plan Update-2017: Nunam Iqua Advisory Planning Board, 52 p.

Overbeck, J.R., ed., 2018, Alaska coastal mapping gaps \& priorities: Alaska Division of Geological \& Geophysical Surveys Information Circular 72, 34 p. http://doi.org/10.14509/30096

Overbeck, J.R., Hendricks, M.D., and Kinsman, N.E.M., 2016, Photogrammetric digital surface models and orthoimagery for 26 coastal commu- nities of western Alaska: in DGGS Staff, Elevation Datasets of Alaska: Alaska Division of Geological \& Geophysical Surveys Raw Data File 2016-1, 3 p. http://doi.org/10.14509/29548

2017, Photogrammetric digital surface models and orthoimagery for the continuous coastline, Wales to Platinum, Alaska: Alaska Division of Geological \& Geophysical Surveys Raw Data File 2017-8, 21 p. http://doi.org/10.14509/29744

Overeem, Irina, Anderson, R.S., Wobus, C.W., Clow, G.D., Urban, F.E., and Matell, Nora, 2011, Sea ice loss enhances wave action at the Arctic coast: Geophysical Research Letters, v. 38, no. L17503, p. 1-6. http://doi.org/10.1029/2011GL048681 Overland, J.E., Hanna, E., Hanssen-Bauer, I., Kim, S.-J., Walsh, J.E., Wang, M., Bhatt, U.S., and Thoman, R.L., 2017, State of the Climate in 2016, Surface air temperature: Bulletin of the American Meteorological Society, v. 98, no. 8, p. S93-98.

Perovich D., Meier, W., Tschudi, M., Farrell, S., Gerland, S., Hendricks, S., Krumpen, T. and Haas, C., 2017, State of the Climate in 2016, Sea ice cover: Bulletin of the American Meteorological Society, v. 98, no. 8, p. S93-98.

Quantum Spatial, 2019, North Slope communities 2019 technical data report: Quantum Spatial, 11 p. Shorezone, 2019, ShoreZone shore types and photos of Alaska. http://shorezone.org

Smith, S.L., Romanovsky, V.E., Lekowicz, A.G., Burn, C.R., Allard, M., Clow, G.D., Yoshikawa, K., Throop, J., 2010, Thermal state of permafrost in North America: a contribution to the international polar year: Permafrost and Periglacial Processes, v. 21, no. 2, p. 117-135. http://doi. org/10.1002/ppp.690

Snyder, A.G., and Gibbs, A.E., 2019, National assessment of shoreline change: A GIS compilation of updated vector shorelines and associated shoreline change data for the north coast of Alaska, Icy Cape to Cape Prince of Wales: U.S. Geological Survey data release. https://doi.org/10.5066/P9H1S1PV Steele, Michael and Dickinson, Suzanne, 2016, The phenology of Arctic Ocean surface warming: Journal of Geophysical Research, Oceans, v. 121, no. 9, p. 6,847-6,861. 
Sweet, W.V., Kopp, R.E., Weaver, C.P., Obeysekera, Jayantha, Horton, R.M., Thieler, E.R., Zervas, Chris, 2017, Global and regional sea level rise scenarios for the United States: National Oceanic \& Atmospheric Administration, NOAA Technical Report NOS CO-OPS 083, 75 p. https://tidesandcurrents.noaa.gov/publications/techrpt83_ Global_and_Regional_SLR_Scenarios_for_the_ US_final.pdf

Terenzi, John, Jorgenson, M. T., and Ely, C.R., 2014, Storm-surge flooding on the Yukon-Kuskokwim Delta, Alaska: Arctic, v. 67, no. 3, p. 360-374.

Thoman, Rick, Walsh, J.E., and McFarland, H.R. eds., 2019, Alaska's changing environment: documenting Alaska's physical and biological changes through observations: International Arctic Research Center, University of Alaska Fairbanks. https://uaf-iarc.org/our-work/alaskaschanging-environment/

Thomas, M.A., Mota, Alejandro, Jones, B.M., Choens, R.C., Frederick, J.M., Bull, D.L., 2020, Geometric and material variability influences stress states relevant to coastal permafrost bluff failure: Front. Earth Sci, v. 8, no. 143., 13 p. http://doi.org/10.3389/feart.2020.00143

Umiaq and Olgoonik Development, LLC, 2014, Wainwright comprehensive plan: North Slope Borough, 124 p. http://www.north-slope.org/ assets/images/uploads/2014_Wainwright_ Comp_Plan_Final.pdf

University of Alaska Fairbanks (UAF) Institute of Northern Engineering, U.S. Army Corps of Engineers Alaska District, U.S. Army Corps of Engineers (USACE) Cold Regions Research and Engineering Laboratory, 2019, Statewide threat assessmentidentification of threats from erosion, flooding, and thawing permafrost in remote Alaska communities: Report \#INE 19.03, 99 p. https://www.denali.gov/ wp-content/uploads/2019/11/Statewide-ThreatAssessment-Final-Report-20-November-2019.pdf

U.S. Army Corps of Engineers (USACE), March 2009, Alaska baseline erosion assessment: study findings and technical report: U.S. Army Corps of Engineers Alaska District, 65 p. http://www.poa. usace.army.mil/Library/Reports-and-Studies/ Alaska-Baseline-Erosion-Assessments/

U.S. Geological Survey (USGS), 2019, Earth Explorer: U.S. Geological Survey. https://earthexplorer.usgs. gov/

U.S. General Accounting Office (GAO), 2003, Alaska Native Villages: most are affected by flooding and erosion, but few qualify for federal assistance: U.S. General Accounting Office, GAO-04-142, 91 p. https://www.gao.gov/ products/GAO-04-142

2009, Alaska Native Villages: limited progress has been made on relocating villages threatened by flooding and erosion: U.S. Government Accountability Office, GAO-09-551, 53 p. https:// www.gao.gov/products/GAO-09-551

Vermaire, J.C., Pisaric, M.F.J., Thienpont, J.R., Mustaphi, C.J.C., Kokelj, S.V., and Smol, J.P., 2013, Arctic climate warming and sea ice declines lead to increased storm surge activity: Geophysical Research Letters, v. 40, no. 7, p. 1,386-1,390.

Whitley, M.A., Frost, G.V., Jorgenson, M.T., Macander, M.J., Maio, C.V., and Winder, S.G., 2018, Assessment of lidar and spectral techniques for high-resolution mapping of sporadic permafrost on the Yukon-Kuskokwim Delta, Alaska: Remote Sensing, v. 10, p. 258.

Wobus, Cameron, Anderson, Robert, Overeem, Irina, Matell, Nora, Clow, Gary, and Urban, Frank, 2011, Thermal erosion of a permafrost coastline: improving process-based models using time-lapse photography: Arctic, Antarctic, and Alpine Research, v. 43, no. 3, p. 474-484a. https://doi.org/10.1657/1938-4246-43.3.474

Wright, J.M., Morris, J.M., and Schroeder, Robert, 1985, Bristol Bay regional subsistence profile: Alaska Department of Fish and Game, technical paper no. 114. http://www.adfg.alaska.gov/ techpap/tp114.pdf 


\section{APPENDIX: SHORELINE POSITION AND AERIAL ORTHOIMAGERY UNCERTAINTIES}

Table A1. Shoreline uncertainty values that remained constant for all communities analyzed here.

\begin{tabular}{lllll}
\multicolumn{1}{c}{ Date } & $\mathbf{U}_{\mathbf{o}}(\mathbf{m})$ & $\mathbf{U}_{\mathbf{i}}(\mathbf{m})$ & $\mathbf{U}_{\mathbf{p}}(\mathbf{m})$ & $\mathbf{U}_{\mathbf{d}}(\mathbf{m})$ \\
\hline 1950 's & See below & 0.17 & 1.00 & See below \\
\hline 1980 's & See below & 0.17 & 1.70 & See below \\
\hline $2015-16$ & See below & 0.035 & 0.20 & See below \\
\hline 2018 & See below & Not Available & 0.20 & See below \\
\hline 2019 & See below & 0.035 & 0.075 & See below
\end{tabular}

Table A2. Shoreline uncertainty values computed for specific communities.

\begin{tabular}{|c|c|c|c|c|c|c|c|}
\hline Community & $\begin{array}{l}\text { Imagery } \\
\text { Date }\end{array}$ & $\begin{array}{l}\text { RMSE }_{r} \text { (Ortho- } \\
\text { rectification } \\
\text { error of } \\
\left.\text { imagery, } U_{o}\right) \\
(m)\end{array}$ & $\begin{array}{l}\text { RMSE }_{\mathrm{r}} \text { (Ortho- } \\
\text { rectification } \\
\text { error of } \\
\text { imagery, } \mathrm{U}_{\mathrm{o}} \text { ) } \\
\text { (ft) }\end{array}$ & $\begin{array}{c}\text { Shoreline } \\
\text { Digitizer Error } \\
U_{n}(\mathrm{fm})\end{array}$ & $\begin{array}{c}\text { Shoreline } \\
\text { Digitizer Error } \\
U_{n}(\mathrm{ft})\end{array}$ & $\begin{array}{l}\text { Shoreline } \\
\text { Position } \\
\text { Accuracy } U_{t} \\
\text { (m) }\end{array}$ & $\begin{array}{c}\text { Shoreline } \\
\text { Position } \\
\text { Accuracy } U_{t} \\
\text { (ft) }\end{array}$ \\
\hline \multirow{4}{*}{ Alakanuk } & 7/21/1951 & 0.98 & 3.22 & 0.29 & 0.95 & 1.44 & 4.72 \\
\hline & $7 / 23 / 1980$ & 0.95 & 3.12 & 0.29 & 0.95 & 1.98 & 6.50 \\
\hline & $8 / 23 / 2006$ & 0.98 & 3.22 & 0.29 & 0.95 & 1.06 & 3.48 \\
\hline & $8 / 31 / 2015$ & 0.46 & 1.51 & 1.55 & 5.09 & 1.63 & 5.35 \\
\hline \multirow{4}{*}{$\begin{array}{l}\text { Brevig } \\
\text { Mission }\end{array}$} & $9 / 21 / 1950$ & 1.32 & 4.33 & 1.55 & 5.09 & 2.27 & 7.45 \\
\hline & 8/1/1985 & 3.25 & 10.66 & 1.55 & 5.09 & 3.98 & 13.06 \\
\hline & $6 / 13 / 2004$ & 1.58 & 5.18 & 0.29 & 0.95 & 1.71 & 5.61 \\
\hline & $8 / 28 / 2015$ & 0.12 & 0.39 & 1.55 & 5.09 & 1.57 & 5.15 \\
\hline \multirow{4}{*}{ Chefornak } & 9/20/1952 & 2.51 & 8.24 & 0.29 & 0.95 & 2.72 & 8.92 \\
\hline & 8/30/1984 & 4.84 & 15.88 & 0.29 & 0.95 & 5.14 & 16.86 \\
\hline & $10 / 2 / 2004$ & 0.55 & 1.80 & 0.29 & 0.95 & 0.86 & 2.82 \\
\hline & $9 / 6 / 2015$ & 0.03 & 0.08 & 1.55 & 5.09 & 1.56 & 5.12 \\
\hline \multirow{3}{*}{ Clark's Point } & 6/11/1951 & 2.74 & 8.99 & 0.34 & 1.12 & 3.32 & 10.90 \\
\hline & 7/16/1980 & 4.34 & 14.24 & 0.34 & 1.12 & 2.88 & 9.45 \\
\hline & 9/6/2018 & 0.05 & 0.17 & 0.34 & 1.12 & 0.40 & 1.30 \\
\hline \multirow{2}{*}{ Deering } & 7/1/1978 & Not Available & Not Available & Not Available & Not Available & 10.4 & 34.1 \\
\hline & $8 / 31 / 2016$ & Not Available & Not Available & Not Available & Not Available & 2.5 & 10.2 \\
\hline \multirow{3}{*}{ Dillingham } & 8/20/1952 & 2.25 & 7.39 & 0.34 & 1.12 & 2.49 & 8.16 \\
\hline & 7/16/1980 & 3.69 & 12.11 & 0.34 & 1.12 & 4.04 & 13.24 \\
\hline & $9 / 6 / 2018$ & 0.05 & 0.17 & 0.34 & 1.12 & 0.40 & 1.30 \\
\hline \multirow{4}{*}{ Eek } & $7 / 24 / 1953$ & 6.86 & 22.51 & 0.29 & 0.95 & 6.94 & 22.77 \\
\hline & 7/17/1980 & 1.73 & 5.68 & 0.29 & 0.95 & 2.39 & 7.84 \\
\hline & $6 / 16 / 2004$ & 1.52 & 4.99 & 0.29 & 0.95 & 1.66 & 5.45 \\
\hline & $8 / 21 / 2015$ & 0.07 & 0.22 & 1.55 & 5.09 & 1.56 & 5.12 \\
\hline
\end{tabular}


Table A2, continued. Shoreline uncertainty values computed for specific communities.

\begin{tabular}{|c|c|c|c|c|c|c|c|}
\hline Community & $\begin{array}{l}\text { Imagery } \\
\text { Date }\end{array}$ & $\begin{array}{l}\text { RMSE }_{\mathrm{r}} \text { (Ortho- } \\
\text { rectification } \\
\text { error of } \\
\left.\text { imagery, } U_{\mathrm{o}}\right) \\
(\mathrm{m})\end{array}$ & $\begin{array}{l}\text { RMSE }_{\mathrm{r}} \text { (Ortho- } \\
\text { rectification } \\
\text { error of } \\
\text { imagery, } \mathrm{U}_{\mathrm{o}} \text { ) } \\
\text { (ft) }\end{array}$ & $\begin{array}{c}\text { Shoreline } \\
\text { Digitizer Error } \\
U_{n}(\mathrm{fm})\end{array}$ & $\begin{array}{c}\text { Shoreline } \\
\text { Digitizer Error } \\
U_{n}(\mathrm{ft})\end{array}$ & $\begin{array}{c}\text { Shoreline } \\
\text { Position } \\
\text { Accuracy } U_{t} \\
\text { (m) }\end{array}$ & $\begin{array}{l}\text { Shoreline } \\
\text { Position } \\
\text { Accuracy } U_{t} \\
\text { (ft) }\end{array}$ \\
\hline \multirow{3}{*}{ Egegik } & $6 / 25 / 1951$ & 0.89 & 2.93 & 0.34 & 1.12 & 1.38 & 4.53 \\
\hline & 8/27/1983 & 1.11 & 3.63 & 0.34 & 1.12 & 1.98 & 6.50 \\
\hline & 9/6/2018 & 0.05 & 0.17 & 0.34 & 1.12 & 0.40 & 1.30 \\
\hline \multirow{3}{*}{ Ekuk } & $6 / 11 / 1951$ & 3.63 & 11.91 & 0.34 & 1.12 & 3.78 & 12.40 \\
\hline & 7/16/1980 & 2.89 & 9.48 & 0.34 & 1.12 & 3.32 & 10.90 \\
\hline & 9/6/2018 & 0.05 & 0.17 & 0.34 & 1.12 & 0.40 & 1.30 \\
\hline \multirow{4}{*}{ Elim } & $6 / 25 / 1951$ & 1.53 & 5.02 & 1.55 & 5.09 & 2.40 & 7.87 \\
\hline & $7 / 24 / 1980$ & 0.88 & 2.89 & 1.55 & 5.09 & 2.47 & 8.10 \\
\hline & $6 / 11 / 2004$ & 0.75 & 2.46 & 0.29 & 0.95 & 0.86 & 2.82 \\
\hline & $8 / 5 / 2015$ & 0.23 & 0.75 & 1.55 & 5.09 & 1.58 & 5.18 \\
\hline \multirow{5}{*}{ Emmonak } & $6 / 14 / 1950$ & 1.20 & 3.94 & 0.21 & 0.69 & 1.58 & 5.18 \\
\hline & 7/23/1980 & 1.63 & 5.35 & 0.21 & 0.69 & 2.07 & 6.79 \\
\hline & 8/1/2006 & 0.80 & 2.62 & 0.21 & 0.69 & 1.02 & 3.35 \\
\hline & 8/31/2015 & 0.00 & 0.00 & 0.21 & 0.69 & 0.27 & 0.89 \\
\hline & 10/15/2016 & 0.00 & 0.00 & 0.21 & 0.69 & 0.54 & 1.77 \\
\hline \multirow{5}{*}{ Golovin } & $6 / 24 / 1951$ & 3.14 & 10.30 & 1.55 & 5.09 & 3.64 & 11.94 \\
\hline & 7/10/1980 & 1.04 & 3.41 & 1.55 & 5.09 & 2.53 & 8.30 \\
\hline & 6/6/2004 & 0.33 & 1.08 & 0.29 & 0.95 & 0.69 & 2.26 \\
\hline & $8 / 23 / 2015$ & 0.26 & 0.85 & 0.29 & 0.95 & 0.44 & 1.44 \\
\hline & $8 / 24 / 2019$ & 0.07 & 0.24 & 0.29 & 0.95 & 0.30 & 0.98 \\
\hline \multirow{4}{*}{$\begin{array}{l}\text { Goodnews } \\
\text { Bay }\end{array}$} & 6/4/1957 & 1.53 & 5.02 & 0.29 & 0.95 & 1.86 & 6.10 \\
\hline & 8/19/1983 & 2.01 & 6.59 & 0.29 & 0.95 & 2.65 & 8.69 \\
\hline & 6/6/2005 & 0.89 & 2.92 & 0.29 & 0.95 & 1.11 & 3.64 \\
\hline & $5 / 5 / 2016$ & 0.21 & 0.69 & 0.29 & 0.95 & 0.41 & 1.35 \\
\hline \multirow{3}{*}{ Hooper Bay } & $7 / 21 / 1951$ & 2.28 & 7.48 & 0.29 & 0.95 & 2.51 & 8.24 \\
\hline & $7 / 5 / 2007$ & 1.36 & 4.46 & 0.29 & 0.95 & 1.52 & 4.99 \\
\hline & $8 / 13 / 2015$ & 0.54 & 1.77 & 1.55 & 5.09 & 1.65 & 5.41 \\
\hline \multirow{4}{*}{ Kaktovik } & $7 / 29 / 1947$ & 11.00 & 36.09 & Not Available & Not Available & 16.00 & 52.50 \\
\hline & $8 / 29 / 2003$ & 3.70 & 12.14 & Not Available & Not Available & 6.00 & 19.69 \\
\hline & $7 / 13 / 2013$ & 0.70 & 2.30 & 0.29 & 0.95 & 0.97 & 3.18 \\
\hline & 9/9/2019 & 0.04 & 0.12 & 0.29 & 0.95 & 0.30 & 0.99 \\
\hline \multirow{4}{*}{ Kipnuk } & 9/20/1952 & 1.10 & 3.61 & 1.55 & 5.09 & 2.15 & 7.05 \\
\hline & $7 / 17 / 1980$ & 3.54 & 11.61 & 0.29 & 0.95 & 3.94 & 12.93 \\
\hline & $10 / 2 / 2004$ & 1.32 & 4.33 & 0.29 & 0.95 & 1.48 & 4.86 \\
\hline & 9/19/2015 & 0.03 & 0.08 & 0.29 & 0.95 & 0.35 & 1.15 \\
\hline
\end{tabular}


Table A2, continued. Shoreline uncertainty values computed for specific communities.

\begin{tabular}{|c|c|c|c|c|c|c|c|}
\hline Community & $\begin{array}{l}\text { Imagery } \\
\text { Date }\end{array}$ & $\begin{array}{l}\text { RMSE }_{\mathrm{r}} \text { (Ortho- } \\
\text { rectification } \\
\text { error of } \\
\left.\text { imagery, } U_{\mathrm{o}}\right) \\
(\mathrm{m})\end{array}$ & $\begin{array}{l}\text { RMSE }_{\mathrm{r}} \text { (Ortho- } \\
\text { rectification } \\
\text { error of } \\
\text { imagery, } \mathrm{U}_{\mathrm{o}} \text { ) } \\
\text { (ft) }\end{array}$ & $\begin{array}{c}\text { Shoreline } \\
\text { Digitizer Error } \\
U_{n}(\mathrm{fm})\end{array}$ & $\begin{array}{c}\text { Shoreline } \\
\text { Digitizer Error } \\
U_{n}(\mathrm{ft})\end{array}$ & $\begin{array}{c}\text { Shoreline } \\
\text { Position } \\
\text { Accuracy } U_{t} \\
\text { (m) }\end{array}$ & $\begin{array}{l}\text { Shoreline } \\
\text { Position } \\
\text { Accuracy } U_{t} \\
\text { (ft) }\end{array}$ \\
\hline \multirow{4}{*}{ Kivalina } & 7/20/1952 & Not available & Not available & Not available & Not available & 2.3 & 7.5 \\
\hline & 7/30/1980 & Not available & Not available & Not available & Not available & 2.2 & 7.2 \\
\hline & 9/19/2003 & Not available & Not available & Not available & Not available & 1.7 & 5.6 \\
\hline & $8 / 29 / 2016$ & Not available & Not available & Not available & Not available & 3.8 & 12.5 \\
\hline \multirow{4}{*}{ Kongiganak } & 6/17/1952 & 1.44 & 4.72 & 0.29 & 0.95 & 1.79 & 5.87 \\
\hline & 7/17/1980 & 2.04 & 6.69 & 0.29 & 0.95 & 2.68 & 8.79 \\
\hline & $9 / 17 / 2004$ & 1.47 & 4.82 & 0.29 & 0.95 & 1.61 & 5.28 \\
\hline & $8 / 12 / 2015$ & 0.07 & 0.22 & 0.29 & 0.95 & 0.36 & 1.18 \\
\hline \multirow{3}{*}{ Kotlik } & 6/14/1951 & 1.77 & 5.81 & 0.29 & 0.95 & 2.06 & 6.76 \\
\hline & $8 / 31 / 2006$ & 0.79 & 2.59 & 0.29 & 0.95 & 1.03 & 3.38 \\
\hline & $8 / 22 / 2015$ & 0.46 & 1.51 & 0.29 & 0.95 & 0.58 & 1.90 \\
\hline \multirow{4}{*}{ Kotzebue } & 7/1/1950 & Not available & Not available & Not available & Not available & 15.7 & 51.5 \\
\hline & 6/1/1951 & Not available & Not available & Not available & Not available & 15.7 & 51.5 \\
\hline & 7/1/1978 & Not available & Not available & Not available & Not available & 10.4 & 34.1 \\
\hline & 9/1/2016 & Not available & Not available & Not available & Not available & 3.1 & 10.2 \\
\hline \multirow{4}{*}{ Koyuk } & $9 / 21 / 1950$ & 1.86 & 6.10 & 1.55 & 5.09 & 2.62 & 8.60 \\
\hline & $7 / 24 / 1980$ & 2.31 & 7.58 & 1.55 & 5.09 & 3.26 & 10.70 \\
\hline & $6 / 24 / 2004$ & 0.71 & 2.33 & 0.29 & 0.95 & 0.97 & 3.18 \\
\hline & $8 / 5 / 2015$ & 0.23 & 0.75 & 0.29 & 0.95 & 0.42 & 1.38 \\
\hline \multirow{4}{*}{ Kwigillingok } & $6 / 20 / 1953$ & 2.04 & 6.69 & 0.29 & 0.95 & 2.30 & 7.55 \\
\hline & 7/17/1980 & 1.83 & 6.00 & 0.29 & 0.95 & 2.52 & 8.27 \\
\hline & $9 / 17 / 2004$ & 0.53 & 1.74 & 0.29 & 0.95 & 0.85 & 2.79 \\
\hline & $8 / 21 / 2015$ & 0.07 & 0.22 & 0.29 & 0.95 & 0.36 & 1.18 \\
\hline \multirow{4}{*}{ Levelock } & 8/2/1951 & 1.97 & 6.48 & 0.34 & 1.12 & 2.24 & 7.35 \\
\hline & 8/4/1982 & 3.52 & 11.55 & 0.34 & 1.12 & 3.88 & 12.73 \\
\hline & $6 / 17 / 2002$ & 1.37 & 4.50 & 0.34 & 1.12 & 1.73 & 5.68 \\
\hline & 9/6/2018 & 0.05 & 0.17 & 0.34 & 1.12 & 0.40 & 1.30 \\
\hline \multirow{3}{*}{ Naknek } & 7/18/1951 & 1.54 & 5.06 & 0.34 & 1.12 & 1.87 & 6.14 \\
\hline & 7/16/1980 & 4.51 & 14.80 & 0.34 & 1.12 & 4.80 & 15.75 \\
\hline & 9/6/2018 & 0.05 & 0.17 & 0.34 & 1.12 & 0.40 & 1.30 \\
\hline \multirow{3}{*}{ Napakiak } & $6 / 17 / 1952$ & 3.68 & 12.07 & 0.49 & 1.61 & 3.88 & 12.73 \\
\hline & 7/20/1980 & 3.36 & 11.02 & 0.49 & 1.61 & 4.57 & 14.99 \\
\hline & $5 / 4 / 2016$ & 0.22 & 0.72 & 0.49 & 1.61 & 0.57 & 1.87 \\
\hline \multirow{3}{*}{ Newtok } & 7/21/1951 & 1.77 & 5.81 & 0.29 & 0.95 & 2.06 & 6.76 \\
\hline & $6 / 6 / 2005$ & 0.70 & 2.30 & 0.29 & 0.95 & 0.97 & 3.18 \\
\hline & $9 / 1 / 2015$ & 0.18 & 0.57 & 0.29 & 0.95 & 0.40 & 1.31 \\
\hline
\end{tabular}


Table A2, continued. Shoreline uncertainty values computed for specific communities.

\begin{tabular}{|c|c|c|c|c|c|c|c|}
\hline Community & $\begin{array}{l}\text { Imagery } \\
\text { Date }\end{array}$ & $\begin{array}{l}\text { RMSE }_{\mathrm{r}} \text { (Ortho- } \\
\text { rectification } \\
\text { error of } \\
\text { imagery, } \mathrm{U}_{\mathrm{o}} \text { ) } \\
(\mathrm{m})\end{array}$ & $\begin{array}{l}\text { RMSE }_{\text {r }} \text { (Ortho- } \\
\text { rectification } \\
\text { error of } \\
\text { imagery, } U_{\mathrm{o}} \text { ) } \\
\text { (ft) }\end{array}$ & $\begin{array}{c}\text { Shoreline } \\
\text { Digitizer Error } \\
U_{n}(\mathrm{fm})\end{array}$ & $\begin{array}{c}\text { Shoreline } \\
\text { Digitizer Error } \\
U_{n}(\mathrm{ft})\end{array}$ & $\begin{array}{l}\text { Shoreline } \\
\text { Position } \\
\text { Accuracy } U_{t} \\
\text { (m) }\end{array}$ & $\begin{array}{l}\text { Shoreline } \\
\text { Position } \\
\text { Accuracy } U_{t} \\
\text { (ft) }\end{array}$ \\
\hline \multirow{3}{*}{ Nome } & 6/23/1951 & 2.27 & 7.45 & 1.55 & 5.09 & 2.93 & 9.61 \\
\hline & 8/2/1985 & 2.36 & 7.74 & 1.55 & 5.09 & 3.30 & 10.83 \\
\hline & $8 / 23 / 2015$ & 0.26 & 0.86 & 0.29 & 0.95 & 0.44 & 1.44 \\
\hline \multirow{4}{*}{ Nunam lqua } & $7 / 22 / 1951$ & 2.20 & 7.22 & 0.29 & 0.95 & 2.44 & 8.01 \\
\hline & 7/23/1980 & 1.77 & 5.81 & 0.29 & 0.95 & 2.48 & 8.14 \\
\hline & $9 / 1 / 2006$ & 0.63 & 2.07 & 0.29 & 0.95 & 0.92 & 3.02 \\
\hline & $8 / 14 / 2015$ & 0.53 & 1.74 & 0.29 & 0.95 & 0.64 & 2.10 \\
\hline \multirow{4}{*}{ Point Hope } & 7/1/1950 & Not available & Not available & Not available & Not available & 15.7 & 51.5 \\
\hline & $6 / 24 / 1978$ & Not available & Not available & Not available & Not available & 10.4 & 34.1 \\
\hline & $8 / 29 / 2016$ & Not available & Not available & Not available & Not available & 3.8 & 12.5 \\
\hline & $8 / 17 / 2019$ & 0.029 & 0.10 & 0.29 & 0.95 & 0.67 & 2.2 \\
\hline \multirow{3}{*}{ Point Lay } & 7/1/1949 & 10.00 & 32.81 & Not available & Not available & 15.70 & 51.51 \\
\hline & 7/16/1982 & 10.00 & 32.81 & Not available & Not available & 10.40 & 34.12 \\
\hline & $9 / 3 / 2016$ & 0.30 & 0.98 & 0.29 & 0.95 & 2.10 & 6.89 \\
\hline \multirow{8}{*}{ Port Heiden } & 6/24/1957 & 2.87 & 9.42 & Not available & Not available & 3.95 & 12.96 \\
\hline & 8/20/1963 & 3.17 & 10.40 & Not available & Not available & 4.38 & 14.37 \\
\hline & 6/22/1973 & 1.63 & 5.35 & Not available & Not available & 3.61 & 11.84 \\
\hline & 8/26/1983 & 2.12 & 6.96 & Not available & Not available & 4.07 & 13.35 \\
\hline & $6 / 17 / 2002$ & 2.10 & 6.89 & Not available & Not available & 2.61 & 8.56 \\
\hline & $6 / 26 / 2009$ & 2.64 & 8.66 & Not available & Not available & 3.16 & 10.37 \\
\hline & $5 / 1 / 2011$ & 2.46 & 8.07 & Not available & Not available & 8.13 & 26.67 \\
\hline & $6 / 17 / 2013$ & 1.04 & 3.41 & Not available & Not available & 2.01 & 6.59 \\
\hline \multirow{4}{*}{ Quinhagak } & 6/20/1952 & 6.86 & 22.51 & 0.29 & 0.95 & 6.94 & 22.77 \\
\hline & 8/5/1982 & 1.79 & 5.87 & 0.29 & 0.95 & 2.49 & 8.17 \\
\hline & $7 / 27 / 2005$ & 1.16 & 3.81 & 0.29 & 0.95 & 1.38 & 4.53 \\
\hline & $5 / 4 / 2016$ & 0.21 & 0.69 & 0.29 & 0.95 & 0.41 & 1.35 \\
\hline \multirow{2}{*}{$\begin{array}{l}\text { Scammon } \\
\text { Bay }\end{array}$} & $7 / 5 / 2007$ & 1.18 & 3.87 & 0.29 & 0.95 & 1.45 & 4.76 \\
\hline & $8 / 15 / 2015$ & 0.54 & 1.77 & 0.29 & 0.95 & 0.64 & 2.10 \\
\hline \multirow{4}{*}{ Shaktoolik } & $6 / 18 / 1950$ & 1.65 & 5.41 & 0.29 & 0.95 & 1.96 & 6.43 \\
\hline & $6 / 24 / 1980$ & 2.06 & 6.76 & 0.29 & 0.95 & 2.69 & 8.83 \\
\hline & $6 / 27 / 2004$ & 1.46 & 4.79 & 0.29 & 0.95 & 1.52 & 4.99 \\
\hline & 8/6/2015 & 0.23 & 0.75 & 0.29 & 0.95 & 0.42 & 1.38 \\
\hline \multirow{4}{*}{ Shismaref } & $8 / 15 / 1950$ & Not available & Not available & Not available & Not available & 2.9 & 9.5 \\
\hline & 8/1/1985 & Not available & Not available & Not available & Not available & 2.7 & 8.9 \\
\hline & 9/19/2003 & Not available & Not available & Not available & Not available & 1 & 3.3 \\
\hline & 8/31/2016 & Not available & Not available & Not available & Not available & 2.5 & 8.2 \\
\hline
\end{tabular}


Table A2, continued. Shoreline uncertainty values computed for specific communities.

\begin{tabular}{|c|c|c|c|c|c|c|c|}
\hline Community & $\begin{array}{c}\text { Imagery } \\
\text { Date }\end{array}$ & $\begin{array}{l}\text { RMSE }_{\mathrm{r}} \text { (Ortho- } \\
\text { rectification } \\
\text { error of } \\
\text { imagery, } U_{\mathrm{o}} \text { ) } \\
(\mathrm{m})\end{array}$ & $\begin{array}{l}\text { RMSE, }_{\mathrm{r}} \text { (Ortho- } \\
\text { rectification } \\
\text { error of } \\
\text { imagery, } \mathrm{U}_{\mathrm{o}} \text { ) } \\
\text { (ft) }\end{array}$ & $\begin{array}{c}\text { Shoreline } \\
\text { Digitizer Error } \\
U_{n}(\mathrm{fm})\end{array}$ & $\begin{array}{c}\text { Shoreline } \\
\text { Digitizer Error } \\
U_{n}(\mathrm{ft})\end{array}$ & $\begin{array}{l}\text { Shoreline } \\
\text { Position } \\
\text { Accuracy } U_{t} \\
\text { (m) }\end{array}$ & $\begin{array}{l}\text { Shoreline } \\
\text { Position } \\
\text { Accuracy } U_{t} \\
\text { (ft) }\end{array}$ \\
\hline \multirow{3}{*}{$\begin{array}{l}\text { South } \\
\text { Naknek }\end{array}$} & $7 / 18 / 1951$ & 1.54 & 5.06 & 0.34 & 1.12 & 1.87 & 6.14 \\
\hline & 7/16/1980 & 4.51 & 14.80 & 0.34 & 1.12 & 4.80 & 15.74 \\
\hline & 9/6/2018 & 0.05 & 0.17 & 0.34 & 1.12 & 0.40 & 1.30 \\
\hline \multirow{3}{*}{ Stebbins } & $7 / 24 / 1951$ & 1.70 & 5.58 & 0.29 & 0.95 & 2.00 & 6.56 \\
\hline & $6 / 27 / 2004$ & 2.33 & 7.64 & 0.29 & 0.95 & 2.42 & 7.94 \\
\hline & 8/6/2015 & 0.23 & 0.75 & 1.55 & 5.09 & 1.58 & 5.18 \\
\hline \multirow{3}{*}{ St. Michael } & 7/8/1951 & 1.72 & 5.64 & 1.55 & 5.09 & 2.53 & 8.30 \\
\hline & $6 / 27 / 2004$ & 1.51 & 4.95 & 0.29 & 0.95 & 1.65 & 5.41 \\
\hline & 8/6/2015 & 0.23 & 0.75 & 1.55 & 5.09 & 1.58 & 5.18 \\
\hline \multirow{4}{*}{ Teller } & $9 / 21 / 1950$ & 2.32 & 7.61 & 1.55 & 5.09 & 2.97 & 9.74 \\
\hline & 8/1/1985 & 1.84 & 6.04 & 1.55 & 5.09 & 2.95 & 9.68 \\
\hline & $6 / 28 / 2004$ & 1.10 & 3.61 & 0.29 & 0.95 & 1.28 & 4.20 \\
\hline & $8 / 28 / 2015$ & 0.12 & 0.39 & 1.55 & 5.09 & 1.57 & 5.15 \\
\hline \multirow{3}{*}{ Togiak } & $7 / 24 / 1953$ & 4.12 & 13.53 & 0.34 & 1.12 & 4.26 & 13.98 \\
\hline & 8/19/1983 & 4.02 & 13.20 & 0.34 & 1.12 & 4.34 & 14.24 \\
\hline & 9/6/2018 & 0.05 & 0.17 & 0.34 & 1.12 & 0.40 & 1.30 \\
\hline \multirow{3}{*}{ Toksook Bay } & 8/24/1955 & 0.75 & 2.46 & 0.29 & 0.95 & 1.29 & 4.23 \\
\hline & $10 / 2 / 2004$ & 0.67 & 2.20 & 0.29 & 0.95 & 0.94 & 3.08 \\
\hline & $9 / 1 / 2015$ & 0.24 & 0.77 & 0.29 & 0.95 & 0.43 & 1.41 \\
\hline \multirow{4}{*}{ Tuntutuliak } & $6 / 17 / 1952$ & 0.85 & 2.79 & 0.29 & 0.95 & 1.36 & 4.46 \\
\hline & $7 / 27 / 1980$ & 1.34 & 4.40 & 0.29 & 0.95 & 2.19 & 7.19 \\
\hline & $9 / 17 / 2004$ & 0.17 & 0.56 & 0.29 & 0.95 & 0.72 & 2.36 \\
\hline & $8 / 12 / 2015$ & 0.22 & 0.72 & 0.29 & 0.95 & 0.43 & 1.41 \\
\hline \multirow{4}{*}{ Tununak } & $8 / 24 / 1955$ & 1.36 & 4.46 & 0.29 & 0.95 & 1.72 & 5.64 \\
\hline & $7 / 17 / 1980$ & 1.77 & 5.81 & 0.29 & 0.95 & 2.48 & 8.14 \\
\hline & $10 / 2 / 2004$ & 0.61 & 2.00 & 1.55 & 5.09 & 1.57 & 5.15 \\
\hline & $9 / 1 / 2015$ & 0.15 & 0.48 & 0.29 & 0.95 & 0.38 & 1.25 \\
\hline \multirow{3}{*}{ Twin Hills } & $6 / 15 / 1952$ & 2.74 & 8.99 & 0.34 & 1.12 & 2.94 & 9.65 \\
\hline & $7 / 28 / 1983$ & 4.34 & 14.24 & 0.34 & 1.12 & 4.65 & 15.26 \\
\hline & 9/6/2018 & 0.05 & 0.17 & 0.34 & 1.12 & 0.40 & 1.30 \\
\hline \multirow{4}{*}{ Unalakleet } & $6 / 26 / 1951$ & 0.76 & 2.49 & 0.29 & 0.95 & 1.31 & 4.30 \\
\hline & 8/28/1981 & 1.13 & 3.71 & 0.29 & 0.95 & 2.07 & 6.79 \\
\hline & $6 / 27 / 2004$ & 2.04 & 6.69 & 0.29 & 0.95 & 2.15 & 7.05 \\
\hline & $8 / 1 / 2015$ & 0.23 & 0.76 & 0.29 & 0.95 & 0.42 & 1.38 \\
\hline
\end{tabular}


Table A2, continued. Shoreline uncertainty values computed for specific communities.

\begin{tabular}{|c|c|c|c|c|c|c|c|}
\hline Community & $\begin{array}{l}\text { Imagery } \\
\text { Date }\end{array}$ & $\begin{array}{l}\text { RMSE }_{\mathrm{r}} \text { (Ortho- } \\
\text { rectification } \\
\text { error of } \\
\text { imagery, } U_{\mathrm{o}} \text { ) } \\
(\mathrm{m})\end{array}$ & $\begin{array}{l}\text { RMSE }_{\text {r }} \text { (Ortho- } \\
\text { rectification } \\
\text { error of } \\
\text { imagery, } U_{\mathrm{o}} \text { ) } \\
\text { (ft) }\end{array}$ & $\begin{array}{c}\text { Shoreline } \\
\text { Digitizer Error } \\
U_{n}(\mathrm{fm})\end{array}$ & $\begin{array}{c}\text { Shoreline } \\
\text { Digitizer Error } \\
U_{n}(\mathrm{ft})\end{array}$ & $\begin{array}{l}\text { Shoreline } \\
\text { Position } \\
\text { Accuracy } U_{t} \\
\text { (m) }\end{array}$ & $\begin{array}{l}\text { Shoreline } \\
\text { Position } \\
\text { Accuracy } U_{t} \\
\text { (ft) }\end{array}$ \\
\hline \multirow{3}{*}{ Utqiagvik } & 8/1/1947 & Not available & Not available & Not available & Not available & 16 & 52 \\
\hline & $7 / 25 / 2005$ & Not available & Not available & Not available & Not available & 6 & 20 \\
\hline & $7 / 24 / 2010$ & Not available & Not available & Not available & Not available & 10 & 33 \\
\hline \multirow{4}{*}{ Wainwright } & 7/1/1949 & 10.00 & 32.81 & Not available & Not available & 16.00 & 52.50 \\
\hline & $9 / 12 / 2011$ & 6.00 & 19.69 & Not available & Not available & 6.00 & 19.69 \\
\hline & $8 / 1 / 2014$ & 0.34 & 1.12 & 0.29 & 0.95 & 0.75 & 2.45 \\
\hline & $8 / 17 / 2019$ & 0.03 & 0.10 & 0.29 & 0.95 & 0.30 & 0.98 \\
\hline \multirow{4}{*}{ Wales } & $7 / 31 / 1950$ & 1.83 & 6.00 & 0.29 & 0.95 & 2.11 & 6.92 \\
\hline & 8/1/1985 & 1.46 & 4.79 & 0.29 & 0.95 & 2.12 & 6.96 \\
\hline & $6 / 28 / 2004$ & 0.29 & 0.95 & 0.29 & 0.95 & 0.74 & 2.43 \\
\hline & $6 / 27 / 2012$ & 1.37 & 4.49 & 0.29 & 0.95 & 2.36 & 7.74 \\
\hline
\end{tabular}

